\title{
A multimodel ensemble approach to assessment of climate change impacts on the hydrology and water resources of the Colorado River Basin
}

\author{
N. S. Christensen and D. P. Lettenmaier \\ Department of Civil and Environmental Engineering Box 352700, University of Washington, Seattle WA 98195, USA
}

Received: 16 November 2006 - Published in Hydrol. Earth Syst. Sci. Discuss.: 13 December 2006

Revised: 27 April 2007 - Accepted: 5 June 2007 - Published: 9 July 2007

\begin{abstract}
Implications of 21 st century climate change on the hydrology and water resources of the Colorado River Basin were assessed using a multimodel ensemble approach in which downscaled and bias corrected output from 11 General Circulation Models (GCMs) was used to drive macroscale hydrology and water resources models. Downscaled climate scenarios (ensembles) were used as forcings to the Variable Infiltration Capacity (VIC) macroscale hydrology model, which in turn forced the Colorado River Reservoir Model (CRMM). Ensembles of downscaled precipitation and temperature, and derived streamflows and reservoir system performance were assessed through comparison with current climate simulations for the 1950-1999 historical period. For each of the 11 GCMs, two emissions scenarios (IPCC SRES A2 and B1, corresponding to relatively unconstrained growth in emissions, and elimination of global emissions increases by 2100) were represented. Results for the A2 and B1 climate scenarios were divided into three periods: 2010-2039, 2040-2069, and 2070-2099. The mean temperature change averaged over the 11 ensembles for the Colorado basin for the $\mathrm{A} 2$ emission scenario ranged from 1.2 to $4.4^{\circ} \mathrm{C}$ for periods $1-3$, and for the $\mathrm{B} 1$ scenario from 1.3 to $2.7^{\circ} \mathrm{C}$. Precipitation changes were modest, with ensemble mean changes ranging from -1 to $-2 \%$ for the $\mathrm{A} 2$ scenario, and from +1 to $-1 \%$ for the B1 scenario. An analysis of seasonal precipitation patterns showed that most GCMs had modest reductions in summer precipitation and increases in winter precipitation. Derived April 1 snow water equivalent declined for all ensemble members and time periods, with maximum (ensemble mean) reductions of $38 \%$ for the A2 scenario in period 3. Runoff changes were mostly the result of a dominance of increased evapotranspiration over the seasonal precipitation shifts, with ensemble mean runoff changes of $-1,-6$, and
\end{abstract}

Correspondence to: D. P. Lettenmaier

(dennis1@u.washington.edu)
$-11 \%$ for the $\mathrm{A} 2$ ensembles, and $0,-7$, and $-8 \%$ for the B1 ensembles. These hydrological changes were reflected in reservoir system performance. Average total basin reservoir storage and average hydropower production generally declined, however there was a large range across the ensembles. Releases from Glen Canyon Dam to the Lower Basin were reduced for all periods and both emissions scenarios in the ensemble mean. The fraction of years in which shortages occurred increased by approximately $20 \%$ by period 3 for both emissions scenarios.

\section{Introduction}

The Colorado River Basin (CRB) includes parts of seven U.S. states and Mexico (Fig. 1). The headwaters lie in the Rocky Mountains of Wyoming and Colorado, from which the river flows some $1400 \mathrm{~km}$ to the Gulf of California. It drains a mostly semi-arid region, with an average of only $40 \mathrm{~cm} /$ year of precipitation over the $630000 \mathrm{~km}^{2}$ basin. $70 \%$ of the Colorado's flow originates as snowmelt, with the annual hydrograph dominated by winter accumulation and spring melt. $85 \%$ of streamflow is generated from $15 \%$ of the area, while the lower basin (below Lees Ferry, AZ) contributes only $8 \%$ of the annual streamflow. The Colorado River also has considerable temporal variability, with a coefficient of variation for annual streamflow of .33 (by comparison, the coefficient of variation for the Columbia River is less than 0.2). From 1906-2003, annual streamflow had a minimum, maximum, and mean of 6.5, 29.6 and 18.6 billion cubic meters (BCM) at Lees Ferry. A recent 500-year reconstruction of Colorado River discharge using tree ring data (Woodhouse et al., 2006) suggests that the long term average annual flow is somewhat lower than for the 1906-2003 reference period - in the range 17.7-18.1 BCM.

Published by Copernicus Publications on behalf of the European Geosciences Union. 


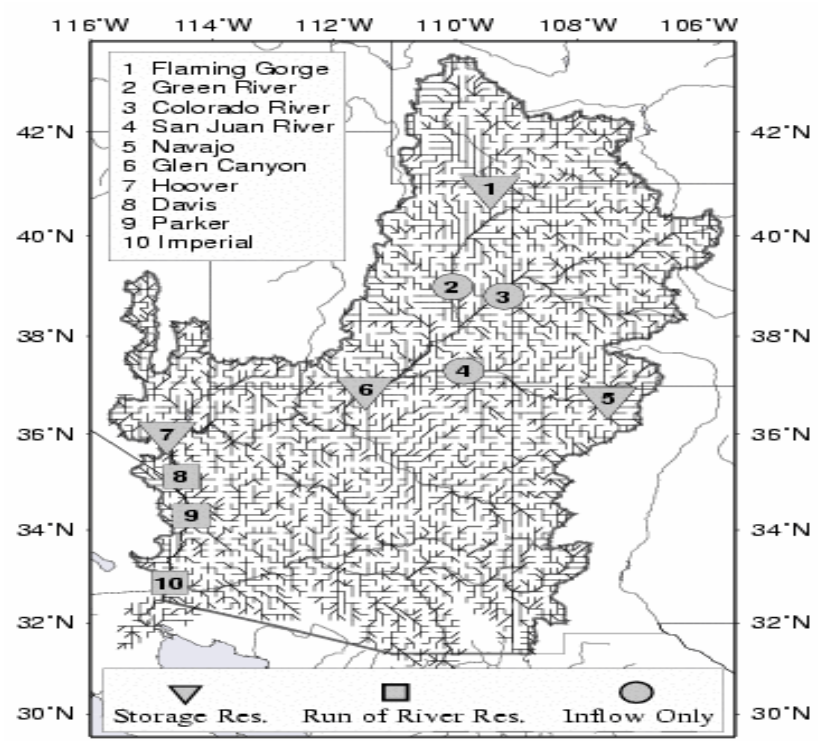

Fig. 1. Colorado River Basin with 1/8 degree VIC routing network and major system reservoirs.

The Colorado River is often described as the most regulated and over allocated river in the world (USDOI, 2000). It has an aggregate reservoir capacity of $74.0 \mathrm{BCM}$, four times its mean annual flow. $85 \%$ of basin storage capacity lies in Lakes Powell (formed by Glen Canyon Dam) and Mead (formed by Hoover Dam). The Law of the River which governs management of the river consists of 12 major and many minor federal and state laws, treaties, court decisions, and compacts and divides the basin's water between the Upper Basin states (Wyoming, Utah, Colorado, and New Mexico), Lower Basin states (Arizona, Nevada, California), and Mexico. The first document of the Law of the River is the Colorado Compact of 1922 which after gauging the river during a period of abnormally high flow apportioned $9.3 \mathrm{BCM} / \mathrm{yr}$ to both the Upper and Lower Basin. Another element of the Law of the River is the U.S.-Mexico Treaty of 1944 which stipulates that Mexico will receive $1.9 \mathrm{BCM} / \mathrm{yr}$ on average at the U.S. - Mexico border. During most of the period since the signing of the compact the 10 year average flow has been below the 20.5 BCM that has been allocated (see Fig. 2) a situation that is further exacerbated by the estimated 1$2 \mathrm{BCM}$ of annual reservoir evaporation. On the other hand, the Compact allocation to the upper basin states has to date not been fully utilized, and for this reason the Law of the River has been able to function notwithstanding the apparent overallocation of the river's water.

The hydrologic implications of climate change are a global concern (Milly et al., 2005), but the CRB is especially vulnerable due to the sensitivity of discharge to precipitation and temperature changes (both of which affect snow accumulation and melt patterns as well as evapotranspiration), effects which are exacerbated by the semi-arid nature of the

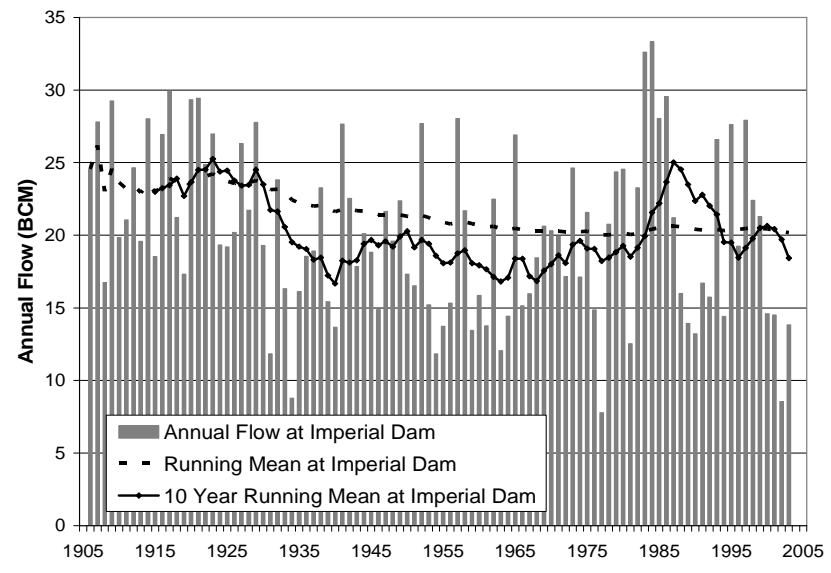

Fig. 2. Annual, 10 year average and running average of natural flow at Imperial Dam, AZ.

basin (Loaiciga, 1996). Global General Circulation Models (GCMs) of the coupled land-ocean-atmosphere system project an increase in global mean surface air temperature between $1.8^{\circ} \mathrm{C}$ and $5.4^{\circ} \mathrm{C}$ between 1990 and 2100 yet disagree upon the tendency and seasonality of precipitation changes (IPCC, 2001) and their spatial distribution regionally. In general, increases in temperature within the CRB will increase the rain to snow ratio, move runoff peaks earlier in the spring, increase evapotranspiration, and decrease annual streamflow, whereas precipitation changes will primarily affect annual streamflow volume (Christensen et al., 2004). The seasonality of precipitation changes, however, contribute to runoff changes as well: a greater percentage of winter precipitation generates runoff than in summer (due to lower evaporative demand).

A previous study of potential climate change in the CRB (Christensen et al., 2004) used the U.S. Department of Energy/National Center for Atmospheric Research Parallel Climate Model (PCM) with a business-as-usual (BAU) global emission scenario (the most recent GCM runs performed for IPCC (2007) no longer use a BAU scenario, however the A2 scenario used in the results we report here is the closest to BAU of those considered). In Christensen et al (2004), average temperature changes of $1.0,1.7$, and $2.4^{\circ} \mathrm{C}$ and precipitation changes of $-3,-6$, and $-3 \%$ were predicted for the CRB for periods 2010-2039 (period 1), 2040-2069 (period 2), and 2070-2099 (period 3), respectively, relative to 1950 1999 means. These temperature and precipitation changes led to reductions of April 1 snow water equivalent (SWE) of 24,29 , and $30 \%$ and runoff reductions of 14,18 , and $17 \%$ for periods 1-3. Other studies (Gleick, 1987; Lettenmaier et al., 1992; Nash and Gleick, 1991, 1993; Hamlet and Lettenmaier, 1999; McCabe and Hay, 1995; McCabe and Wolock, 1999; Wilby et al., 1999; Wolock and McCabe, 1999) of climate change impacts on hydrology and water resources of western U.S. river basins have used both climate signals from 
GCMs as well as prescribed temperature and precipitation changes. All studies have assumed or predicted increasing temperatures, but have disagreed upon both the magnitude and direction of precipitation changes. Aside from Christensen et al. (2004), only one of these studies (Nash and Gleick, 1991, 1993) has been specific to the CRB. Nash and Gleick assessed the impacts of a doubling of $\mathrm{CO}_{2}$ concentrations (at the time of their study, so-called transient GCM output was not widely available). In addition, Nash and Gleick (1991) evaluated prescribed changes of $+2^{\circ} \mathrm{C}$ and $+4^{\circ} \mathrm{C}$ coupled with precipitation reductions of $-10 \%$ and $-20 \%$. The $2^{\circ} \mathrm{C}$ increase $/ 10 \%$ precipitation decrease resulted in a $20 \%$ streamflow reduction while the $4^{\circ} \mathrm{C}$ increase $/ 20 \%$ precipitation decrease resulted in a $30 \%$ runoff decrease. A related study by Nash and Gleick (1993) which analyzed scenarios with both increases and decreases in precipitation suggested that slight increases in precipitation would be offset by increased evapotranspiration, with the net result being reductions in streamflow ranging from 8 to $20 \%$. Wolock and McCabe (1999) utilized climate output from GCMs to drive a hydrology model and concluded that a slight increase in precipitation with modest temperature increase would result in decreased streamflow, while for another GCM a significant increase in precipitation coupled with a larger temperature increase would result in increased streamflow. The diversity of scenarios considered by the assortment of climate change studies reflects the considerable uncertainty in the expected amount of warming and in the magnitude and direction of potential precipitation changes.

The managed water resources of the CRB are highly sensitive to runoff reductions due to the almost complete allocation of streamflow to consumptive uses. The past studies suggest that increased temperature alone, unless offset by increases in precipitation, will stress the water resources of the $\mathrm{CRB}$, while any precipitation decrease will exacerbate these stresses. Nash and Gleick (1993) found reservoir system storage was highly sensitive to changes in runoff, suggesting that the system is currently in a rather fragile balance. Christensen et al. (2004) found that runoff reductions of 14$18 \%$ resulted in system storage reductions of $30-40 \%$ and target releases from Glen Canyon Dam being met 17-32\% less often than in the reference (1950-1999) historic period. Nash and Gleick (1993) found that violations of the Compact would occur if average runoff dropped by only $5 \%$. On the one hand, the large storage to runoff ratio of the basin mitigates the effects of seasonal shifts in runoff timing associated with a warmer climate; even though the large storage capacity will have little effect on long term reliability of water deliveries if average flows decline.

The present study utilizes 11 GCMs under IPCC Special Report on Emission Scenarios (IPCC, 2000) emission scenarios $\mathrm{A} 2$ and $\mathrm{B} 1$, where $\mathrm{A} 2$ corresponds to relatively unconstrained growth in global emissions, and B2 corresponds to elimination of global emissions increases by 2100 . Each GCM's historical simulation was used to bias correct and downscale the temperature and precipitation signals from the A2 and B1 scenarios using methods outlined in Wood et al. (2002) and Wood et al. (2004). The bias corrected and downscaled temperature and precipitation signals were then used to drive the Variable Infiltration Capacity (VIC) macroscale hydrology model (Liang et al., 1994; Nijssen et al., 1997) at a daily time step. Monthly aggregates of VIC-simulated streamflow at selected reservoir inflow points (Fig. 1) were used to force the CRRM. CRRM, described in more detail in Christensen et al. (2004) is a simplified version of the Colorado River Simulation System (USDOI, 1985). It predicts storage in the main CRB reservoirs, and deliveries of water to major water users, as well as hydropower generation. We summarize results of both the VIC and CRRM simulations for period 1 (2010-2039), period 2 (2040-2069, and period 3 (2070-2099), and compare them with a "historical" simulation driven by 1950-1999 observations.

\section{Approach}

\subsection{General circulation models and emission scenarios}

The 11 GCMs which produced the climate scenarios used in this study are summarized in Table 1, which includes references to the details of each model. Although many other GCM runs were prepared for the IPCC Fourth Assessment Report (AR4; IPCC, 2007), these 11 model runs are the most consistent in terms of the future simulation period (all were run for at least the period 2000-2100), and the emissions scenarios used. These GCMs represent the major global modeling centers and provide the basis for the most thorough climate study of the CRB to date. In that respect, we note that our approach here is a generalization of Christensen et al. (2004), who ran one model and emissions scenario for the CRB using essentially the same methods as were used in this study, and Maurer (2007), who ran 10 of the same 11 models we use, and the same emissions scenarios for California.

For its Fourth Assessment Report, the IPCC created six plausible global greenhouse gas emissions scenarios; A1F, A1B, A1T, A2, B1, and B2. With respect to global emissions of greenhouse gases (and hence, in general, global average temperature increases) from warmest to coolest are scenarios A1FI, A2, A1B, B2, A1T, and B1. The A2 and B1 scenarios were chosen for this study because they are the most widely simulated over all models (not all modeling groups have archived runs for all emissions scenarios), and because they represent a plausible range of conditions over the next century.

In the $\mathrm{A} 2$ scenario, global average $\mathrm{CO}_{2}$ concentrations reach 850 ppm by 2100 , while in the $\mathrm{B} 1$ scenario $\mathrm{CO}_{2}$ concentrations initially increase at nearly the same rate as in the A2 scenario, but then level off around mid-century and end at $550 \mathrm{ppm}$ by 2100 (IPCC, 2000). Christensen et al. (2004) used Parallel Climate Model (PCM) runs with the BAU 
Table 1. General Circulation Models used to produce scenarios assessed in this study.

\begin{tabular}{llll}
\hline Abbreviation & Modeling Group/Country & IPCC Model ID & Reference \\
\hline CNRM & Centre National de Recherches Météoroliques, France & CNRM-CM3 & Salas-Mélia et al. (2006) \\
CSIRO & CSIRO Atmospheric Research, Australia & CSIRO-Mk3.0 & Gordon, H. B. et al. (2002) \\
GFDL & Geophysical Fluid Dynamics Laboratory, USA & GFDL-CM2.0 & Delworth et al. (2006) \\
GISS & Goddard Institute for Space Studies, USA & GISS-ER & Russell et al. (1995, 2000) \\
HADCM3 & Hadley Center for Climate and Prediction and Research, UK & UKMO-HadCM3 & Gordon et al. (2002) \\
INMCM & Institute for Numerical Mathematics, Russia & INM-CM3.0 & Diansky and Volodin (2002) \\
IPSL & Institut Pierre Simon Laplace, France & IPSL-CM4 & IPSL (2005) \\
MIROC & Center for Climate Systems Research, Japan & MIROC3.2 & K-1 model developers (2004) \\
MPI & Max Planck Institute for Meteorology, Germany & ECHAM5/MPI-OM & Jungclaus et al. (2006) \\
MRI & Meteorological Research Institute, Japan & MRI-CGCM2.3.2 & Yukimoto et al. (2001) \\
PCM & U.S. Department of Energy/ & PCM & Washington et al. (2000) \\
& National Center for Atmospheric Research, USA & & \\
\hline
\end{tabular}

emissions scenario which as noted above is most comparable to A2 of the emissions scenarios used in IPCC AR4.

Details of the bias correction and downscaling approach used to translate GCM output into VIC input are reported in Wood et al. (2002, 2004) and Maurer (2007). In brief, the method downscales monthly simulated and observed temperature and precipitation probabilities at the GCM spatial scale (regridded to a common 2 degrees latitude by longitude spatial resolution) to the $1 / 8$ degree resolution at which the VIC hydrology model was applied through use of a probability mapping procedure that is "trained" to monthly empirical probability distributions of the climate model output for current climate conditions to equivalent space-time aggregates of the gridded (one-eighth degree spatial resolution) observation set of Maurer et al. (2002). The climate model signal was then temporally and spatially disaggregated through use of a resampling approach to create a daily forcing time series for the hydrology model at the same one-eighth degree spatial resolution. This method facilitates investigation of the implications of the true transient nature of climate warming as opposed to the more common methods employed where decadal temperature and precipitation shifts are averaged to give a step-wise evolution of climate (e.g. Hamlet and Lettenmaier, 1999). It should be noted that the bias correction and downscaling technique that we used by construct reproduce observed climatologies in the special case where the GCM runs have no precipitation and temperature change.

\subsection{VIC model application to the CRB}

Liang et al. (1994) and Nijssen et al. (1997) provide details of the VIC model and its application to continental river basins, while Christensen et al. (2004) provide details of its application to the $\mathrm{CRB}$, hence our description here is highly condensed. VIC is a grid cell based macroscale hydrology model that typically runs at spatial resolutions ranging from one-eighth to two degrees latitude by longitude. The VIC model is forced by gridded temperature, precipitation, and wind time series, as well as other surface radiative and meteorological variables that are derived from daily mean temperature and temperature minima/maxima following methods outlined by Maurer et al. (2002). The VIC model can be run either at a sub-daily time step which facilitates a full energy balance, or (as was used in this study) at daily time step in water balance mode. The model simulates soil moisture dynamics, snow accumulation and melt, evapotranspiration, and generates surface runoff and baseflow which are subsequently routed through a grid based river network to simulate streamflow at selected points within the basin.

As in Christensen et al. (2004), VIC grid cell runoff was routed to locations representing the inflow to seven major reservoirs and three inflow-only locations used in the reservoir simulation model (Fig. 1). VIC was calibrated by forcing the model with historic climate observations and adjusting parameters that govern infiltration and base flow recession to match simulated streamflow with naturalized observed obtained from the U.S. Bureau of Reclamation (2000) at selected points for the same period of record. The overlapping period of record between the Maurer et al. (2002) data set (and therefore historic simulated streamflow) and observed naturalized streamflow is 1950-1999, during which VIC cumulative simulated streamflow was 768 BCM and observed naturalized streamflow was 776 BCM. This represents a VIC bias to slightly underpredict streamflow (by about one percent). The relative biases at Green River, UT and the Colorado River near Cisco, UT, were slightly larger (3 and $-9 \%$, respectively). The additional step of first bias correcting these streamflows before driving CRRM with them was added; this is a step that was not included in the Christensen et al. (2004) study. Snover et al. (2003) provide details, but this step essentially maps between simulated and observed probability distributions at each CRRM inflow point in each calendar month during the overlapping 1950-1999 period. This same relationship is then applied to the future GCM runs, therefore eliminating any systematic spatial bias. 


\subsection{CRRM implementation}

CRRM is a simplified version of the U.S. Bureau of Reclamation's (USBR) Colorado River Simulation System (CRSS) (Schuster, 1987; USDOI, 1985) developed by Christensen et al. (2004) for assessment of the affects of altered streamflow regimes on performance of the Colorado River reservoir system. CRRM is driven by naturalized streamflow (VIC output) at the inflow points shown in Fig. 1. It represents all major physical water management structures in the CRB. Pre-specified operating policies are used to simulate reservoir levels and releases, hydropower production, and diversions on a monthly time step.

Because of the large fraction of total CRB reservoir storage in Lakes Powell and Mead, not all of the physical or operational complexities of the river system need to be represented in CRRM to enable the assessment of climate change implications of reservoir system performance. CRRM therefore represents the CRB reservoir system with four storage and three run-of-the-river reservoirs. The storage reservoirs are Flaming Gorge, Navajo, Lake Powell, and Lake Mead, of which only Lakes Powell and Navajo are essentially equivalent to the true reservoirs. Flaming Gorge includes the storage capacity of Fontenelle and Lake Mead includes the storage capacity of the downstream reservoirs that are treated as run-of-the-river in CRRM. Hydropower is simulated at all reservoirs except Navajo and Imperial.

As noted above, the operating policies of the CRB reservoir system are dictated by the Law of the River. In CRRM, like CRSS, these laws have been simplified so that the main regulations affecting operations are a mandatory release of 10.2 BCM per year from Glen Canyon Dam (for the Lower Basin's 9.2 BCM/yr entitlement and one-half of Mexico's $1.9 \mathrm{BCM} / \mathrm{yr}$ ) and an annual release from the Lower Basin to Mexico of 1.9 BCM. CRRM, again like CRSS, requires the release from Lake Powell regardless of the reservoir level relative to its minimum power pool; only when it is not physically possible to release water (dead storage) are releases to the Lower Basin curtailed. CRRM shortage delivery operations were updated in CRRM relative to the version of the model used in Christensen et al. (2004) to reflect the "basin states alternative" (BSA) which is likely to be adopted as the basis for water deliveries in the future. The BSA has three different shortage levels $(494,617$, and $740 \mathrm{MCM} / \mathrm{yr}$ that are imposed at Lake Mead elevations of 327.66, 320.05, and $312.42 \mathrm{~m}$, respectively. The BSA also stipulates a hard protect of the Southern Nevada's Water Authority (SNWA) intake at an elevation of $304.80 \mathrm{~m}$. At this elevation deliveries to the lower basin will be reduced, to zero if need be, to ensure no further reduction of elevation. The first three reductions are weighted $79 \%$ to CAP, $17 \%$ to Mexico, and $4 \%$ to SNWA. The BSA does not stipulate how shortages are allocated after the $740 \mathrm{MCM} / \mathrm{yr}$ level; however CRRM follows the Law of the River and recognizes CAP's allocation to be junior to the MWD, which in turn is junior to the Im- perial Irrigation District (IID). CRRM, like CRSS, does not impose shortages on the Upper Basin but rather passes them onto the Lower Basin even though this could be considered a violation of the Law of the River (Hundley, 1975).

Water demands in this study were based on the USBR's Multi-Species Conservation Program (MSCP) (USDOI, 2000) baseline demands for year 2000. Upper Basin demands were fixed at 5.2 BCM/yr and Lower Basin at their full entitlement of 9.2 BCM/yr. Although demands will likely increase as population increases in the basin, holding demands steady allows us to isolate the effects climate change from the confounding effects of transient demand increase. CRRM represents withdrawals from the river at 11 diversion points, each of which has a unique monthly return ratio (fraction of water diverted that is returned to the river). If there is insufficient water within a river reach or reservoir to meet a demand, the two upstream reservoirs are allowed to make releases to fulfill the demand. Present perfected water rights are not explicitly modeled in CRRM, instead priority is given to upstream users except in the case of Lower Basin shortages.

Christensen et al. (2004) provide validation plots of CRRM during the period 1970-1990, in which it had a 1\% monthly storage error and a $0 \%$ accumulated error over the 20 year period. During this period it had a $12 \%$ accumulated hydropower error, but the error was largely due to the high reservoir levels in the mid-80s coupled with CRRM's lack of inflow forecasting. Given results reported in the following section, it appears unlikely that these high reservoir levels will be reached in the future, so CRRM arguably represents hydropower production adequately for the purpose of this study.

\section{Results}

In this section we analyze downscaled and bias corrected GCM climate scenarios (using the method of Wood et al, 2004) which we compare to 1950-1999 gridded historical observations of daily temperature and precipitation from Maurer et al. (2002). Hydroclimatic variables (runoff, SWE, evaporation) simulated by VIC for the GCM scenarios are compared to VIC simulations driven by the 1950-1999 climate observations. Baseline statistics for the 1950-1999 period are termed "historical", while GCM results are divided into period 1 (2010-2039), period 2 (2040-2069), and period 3 (2070-2099). We discuss in this section ensemble means and quartiles (which, taken together, give an idea of the range of the resuls), whereas more detailed results for individual GCMs and emission scenarios are reported in Appendix A. 

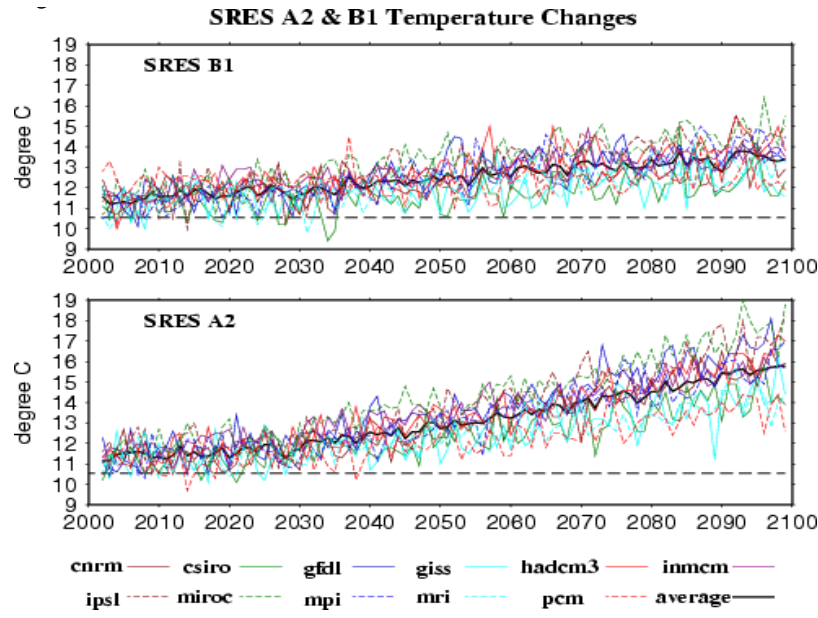

Fig. 3. Basin averaged temperature change for SRES A2 and B1 emission scenarios.

\subsection{Downscaled climate change scenarios}

Figure 3 shows the transient basin average temperature for each of the 11 GCMs throughout the 21st century under both the A2 and B1 emission scenarios. Although there is considerable spread within each scenario, it is apparent that by the second half of the century there is significantly more warming associated with the A2 than the B1 scenario. By period 2, all the climate models with the exception of PCM simulate warmer temperatures for the $\mathrm{A} 2$ scenario, and by period 3 all GCMs simulate warmer A2 temperatures (average warming of $2.7^{\circ} \mathrm{C}$ in $\mathrm{B} 1 \mathrm{vs}$. warming of $4.4^{\circ} \mathrm{C}$ in the $\mathrm{A} 2$ scenario). Table 2 summarizes ensemble average changes while Tables A1 and $\mathrm{A} 2$ report results for individual ensemble members.

Figure 4 shows the shift in annual distribution of temperature and precipitation, and resulting runoff for periods 1-3 relative to the 1950-1999 historic simulation. Results are presented for the ensemble average and 1st and 3rd quartiles. As expected (because A2 and B1 emission scenarios are similar for the first part of the century) there is little difference in warming between the two scenarios during period 1. The ensemble average $\mathrm{B} 1$ period 1 warming is $1.28^{\circ} \mathrm{C}$ (1st and 3rd quartiles 1.02 and $1.67^{\circ} \mathrm{C}$ ) while $\mathrm{A} 2$ is $1.23^{\circ} \mathrm{C}$ $\left(0.95,1.49^{\circ} \mathrm{C}\right)$. By period 2 the $\mathrm{B} 1$ scenario has a mean shift of $2.05^{\circ} \mathrm{C}\left(1.64,2.48^{\circ} \mathrm{C}\right)$. In the same period, the mean $\mathrm{A} 2$ shift is $2.56^{\circ} \mathrm{C}\left(1.94,2.83^{\circ} \mathrm{C}\right)$. By period 3, scenario A2 is $1.7^{\circ} \mathrm{C}$ warmer than $\mathrm{B} 1$. B1 has a mean shift of $2.74^{\circ} \mathrm{C}(1.89$, $\left.3.23^{\circ} \mathrm{C}\right)$ while $\mathrm{A} 2$ is $4.35^{\circ} \mathrm{C}\left(3.32,5.38^{\circ} \mathrm{C}\right)$. The ensemble averages for all scenarios and time periods have more warming from mid-summer to early fall, which may be attributable to fact that there is less moisture during these months than in the historical simulation, and therefore more energy going to sensible than to latent heating.
GCMS AVERAGE DEPARTURES FROM 1950-1999 MEAN

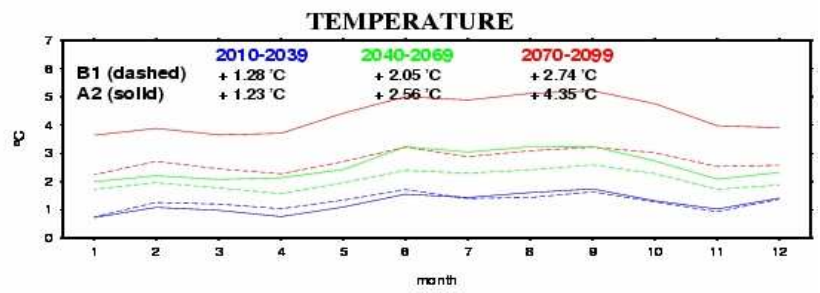

PRECIPITATION
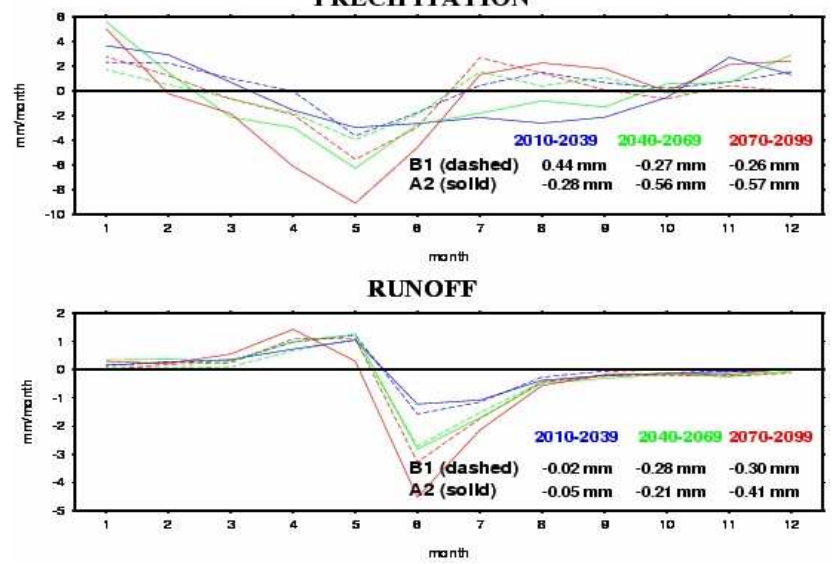

Fig. 4. Changes in annual average temperature, precipitation, and runoff for periods 1, 2, and 3 for SRES scenarios A2 and B1.

Averaged over all GCMs ("ensemble average"), changes in average annual precipitation are $-1(-6,+3),-2(-7$, $+7)$, and $-2(-8,+5) \%$ for the A2 scenario, and $+1(-3$, $+6),-1(-6,+4)$, and $-1(-8,+2) \%$ for the B1 emission scenario for periods $1-3$, respectively (Fig. 5). Although the trend is for very slight decreases in the ensemble mean precipitation, and hence runoff decreases are driven primarily by increased evapotranspiration, there are ensemble members where increased precipitation offsets increased evaporative losses resulting in increased runoff. The number of ensemble members with this character in general decreases with time for both emissions scenarios (see Appendix A for individual ensemble member results). Also, although annual precipitation decreases very slightly in the annual mean, ensemble average winter precipitation increases (Fig. 4b). The increase in winter (October-March) precipitation is 5, 1, and $2 \%$ for the B1 scenario, and 6,5 , and $4 \%$ for the A2 scenario for periods 1-3, respectfully. Upstream of Lees Ferry (where a larger percentage of precipitation results in runoff), the $\mathrm{B} 1$ scenario has a $7 \%$ winter precipitation increase in period 1 and 6 and $8 \%$ increases in periods 2 and 3 . In the A2 scenario, the increase in winter precipitation upstream of Lees Ferry is 8,10 , and $14 \%$ in periods $1-3$, respectively. In section 3.4 we perform a separate sensitivity analysis of the implications of these changes, but in short, a shift towards winter precipitation results in more runoff for a given precipitation amount. These increases in winter precipitation 


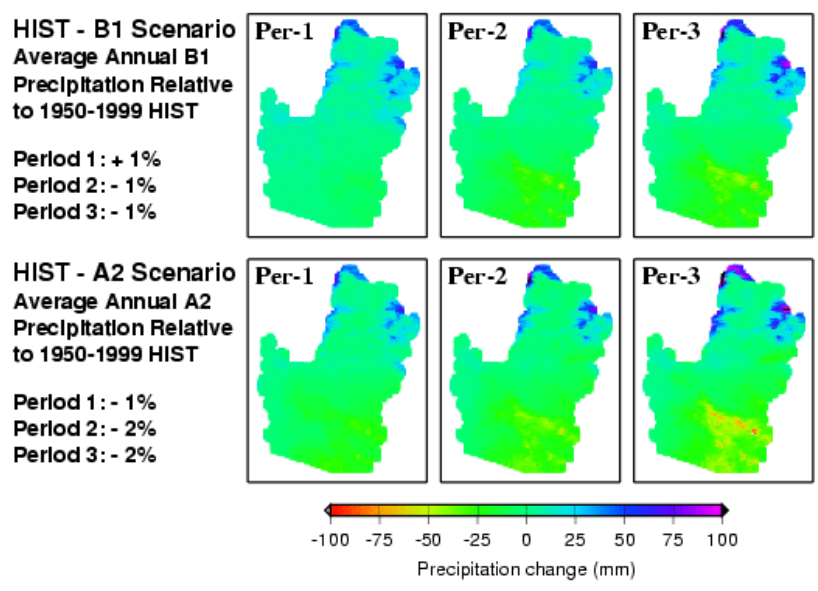

Fig. 5. Annual average precipitation changes for periods 1-3 relative to 1950-1999 historic simulation.

amounts are opposite to the projections by the earlier version of PCM utilized in Christensen et al. (2004). The ensemble averages in that study had winter precipitation decreases of 4,6 , and $4 \%$ for periods $1-3$, respectfully, which drove much larger reductions in (annual) streamflow than projected in this study (see below).

Figure 5 shows the spatial distribution of predicted changes in annual precipitation. Increases are predominantly in the high elevation areas of the Rockies in Colorado, Wyoming and Utah while decreases are greatest in the desert portions of the southeast basin in Arizona and New Mexico. It should be noted that the fine spatial resolution of the predicted precipitation changes in Fig. 5 is in fact driven by the coarse spatial resolution of the GCM output. The regions in Fig. 5 that show the greatest precipitation increases are in general the areas that have high precipitation in the same months for which the GCMs predict increases. The mountainous headwaters regions, for example, receive a preponderance of their precipitation in the winter, and because the GCMs on average have winter precipitation increases, the mountain headwaters have the greatest annual average precipitation increases. The converse holds for summer; decreases in basin wide summer precipitation cause the greatest annual (volume) reductions to occur in the southeast since this region receives most of its rainfall during the summer months.

\subsection{Runoff changes}

Figure 6a shows spatial changes in the ensemble average mean annual runoff for periods $1-3$ relative to simulated historic, and Fig. $6 \mathrm{~b}$ shows the mean monthly hydrograph for three streamflow locations in the basin. 1950-1999 basin average annual precipitation is $354 \mathrm{~mm}$, of which $310 \mathrm{~mm}$ evaporates, leaving $45 \mathrm{~mm}$ to runoff. This constitutes a runoff ratio of around $13 \%$ which is typical of semi-arid wa- (a)
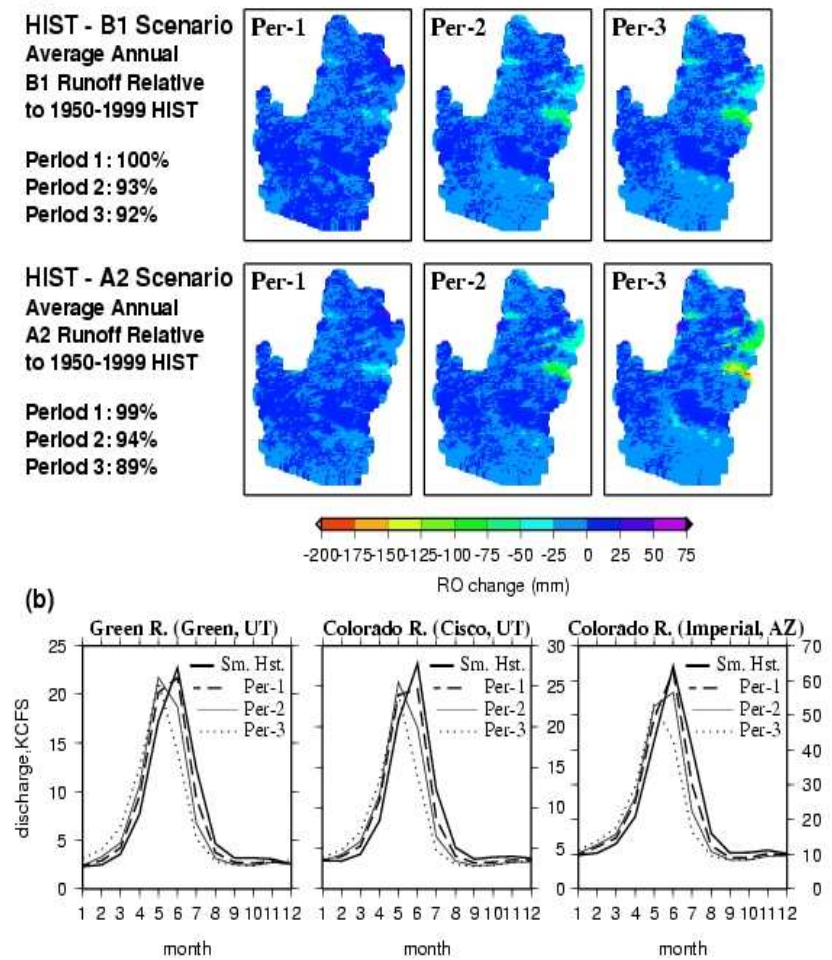

Fig. 6. (a) Spatial distribution of predicted (ensemble mean) changes in mean annual runoff for periods $1-3$ relative to simulated historic, and, (b) mean monthly hydrograph for the Green River at Green River, UT, Colorado River near Cisco, UT, and Colorado River below Imperial, AZ for simulated historic discharge, and ensemble means for Periods 1-3.

tersheds (Nash and Gleick,, 1991). Runoff stays essentially unchanged in period 1 for both SRES scenarios, decreases by $7(-15,0)$ and $6(-14,+8) \%$ in period 2 for the B1 and $\mathrm{A} 2$ scenarios, respectively, and by $8(-18,-1)$ and 11 $(-16,-1) \%$ in period 3 for the $\mathrm{B} 1$ and $\mathrm{A} 2$ scenario. Table 2 shows average annual precipitation, evaporation, and runoff in $\mathrm{mm} / \mathrm{year}$, and runoff ratio and basin average annual temperature. Although precipitation changes are modest $(+1--2 \%)$, changes (mostly decreases) in runoff ratio are larger. The runoff ratio reductions are driven both by temperature (the higher the temperature, the lower the runoff ratio) as well as by shifts in the seasonality of precipitation (see Sect. 3.4). For individual GCM ensemble members in which there are comparable temperature and precipitation changes, the runs that have larger shifts towards winter precipitation have higher runoff ratios. In Christensen et al. (2004) we utilized an earlier version of PCM which projected slightly greater precipitation decreases, smaller temperature increases, and from which substantially larger runoff decreases were inferred. For period 3 annual average temperature increases of $2.4^{\circ} \mathrm{C}$ and precipitation decreases of $3 \%$ drove a runoff decrease of $17 \%$. As noted above, this 


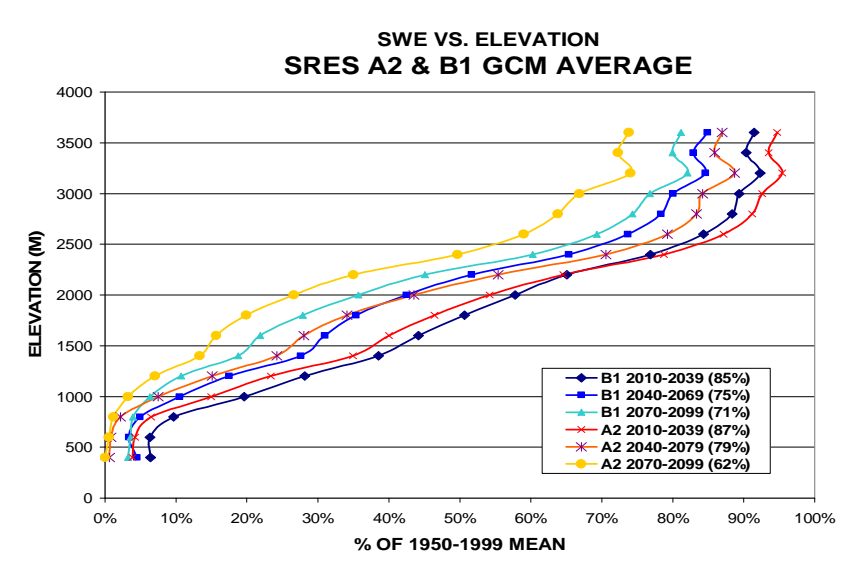

Fig. 7. Changes in annual average snow water equivalent "present" by elevation for periods $1-3$ relative to simulated historical.

large runoff decrease for the modest temperature and precipitation change (relative to the ensemble means in this study) is a result in large part of the earlier PCM's shift away from winter precipitation.

Although a reduction of $5 \mathrm{~mm} /$ year of runoff may seem modest, it represents a reduction of $11 \%$ which has major implications on a system whose water is already over-allocated.

\subsection{Snowpack changes}

Basin average April 1 snow water equivalent (SWE), the depth of water that the snowpack would produce if melted, declines by $13(25,6), 21(29,16)$, and $38(48,19) \%$ in scenario A2, and by $15(24,11), 25(31,18)$, and $29(33,19) \%$ in scenario B1 in periods $1-3$, respectively. Winter precipitation is greater for all ensemble means relative to the historical period, leading to the conclusion that the reductions in SWE are directly attributable to higher winter temperatures and the resulting decrease in the ratio of precipitation falling as snow vs. rain. Reductions in SWE present are greatest in the low to mid elevation transitional zone (Fig. 7). The metric "snow present" is a function of both SWE depth and the amount of time the SWE is present. If an equivalent amount of snow falls, but melts twice as fast, it is considered $50 \%$ of historical. These results are consistent with Nash and Gleick (2003), Wilby et al. (1999), McCabe and Wolock (1999), Brown et al. (2000), and Christensen et al. (2004).

\subsection{Sensitivity of runoff to seasonality of precipitation}

A separate analysis was performed to better understand the effect that a seasonal shift in precipitation would have on runoff generation. To do this we compared runoff generated by a base run to simulations in which winter (OctoberMarch) and summer (April-September) precipitation was individually increased and decreased by $10 \%$ (Table 3 ). The results show, as expected, that a higher percentage of winter vs. summer precipitation results in runoff. Comparison of
Tables 2 and 3 suggests that $38 \%$ of the increase in winter precipitation results in runoff, while only $23 \%$ of the summer precipitation increase contributes to streamflow. The same trend holds for precipitation decreases, with comparable decreases in precipitation leading to almost twice as much runoff decrease in winter than summer. This analysis confirms that the slight shift towards increased winter precipitation in the ensemble means helps offset some of the effects of increased temperature on evapotranspiration.

\subsection{Reservoir system performance}

The managed water resources of the CRB are extremely sensitive to changes in the mean annual flow of the river due to its almost complete allocation of streamflow to consumptive uses. As noted above, the Colorado River Compact of 1922 was based on abnormally high flow years in which the average streamflow of the river was around 22.2 BCM/yr, of which $20.4 \mathrm{BCM} / \mathrm{yr}$ was allocated to consumptive use. The results we report are based on consumptive use of 17.5 BCM/yr (Mexico and the Lower Basin utilizing their full allocation, and the Upper Basin fixed at their actual year 2000 consumptive use of $6.4 \mathrm{BCM} / \mathrm{yr}$ ). Annual reservoir evaporation is a function of storage (i.e. surface area), however it is on average greater than one BCM per year, making total consumptive losses (use + evaporation) over $18.8 \mathrm{BCM} / \mathrm{yr}$.

The 1906-1999 average discharge of the river at its mouth (without regulation) would be $20.4 \mathrm{BCM} / \mathrm{yr}$, with 10 -year average flows as low as $16.3 \mathrm{BCM} / \mathrm{yr}$, however the system has been able to operate reliably in the past due to Upper Basin demand being lower than current levels. Any reduction in streamflow will exacerbate the stress of increasing Upper Basin demands and reduce system reliability. In 32 of the 66 ensemble members (2 SRES scenarios, 3 time periods, 11 climate models), average streamflow is below the current consumptive use (domestic depletions plus reservoir evaporation plus Mexico release) of $18.8 \mathrm{BCM} / \mathrm{yr}$. In only eight of the B1 ensembles and six of the A2 ensembles (none in 2070-2099) are there no delivery shortages.

We assess changes in reservoir system performance associated with the future climate ensembles through the next century by comparing CRRM output for simulations driven by future VIC streamflow sequences with CRRM simulations driven by VIC 1950-1999 historical simulations. We show results in this section for total basin storage, water delivery reliability, Law of the River compliance, and hydropower production.

It should be noted that the historic reservoir simulation has lower average storage and hydropower generation than ensembles that have essentially the same average streamflow. This is a result of the early part of the 1950-1999 record having low inflow, and therefore starting with low storage (head in the case of hydropower). In these simulations, initial reservoir storage was iterated so that the starting value 
Table 2. Annual average precipitation, evaporation, and runoff (in mm/year), runoff ratio, and basin average temperature $\left({ }^{\circ} \mathrm{C}\right.$ ).

\begin{tabular}{llllll}
\hline Scenario, Per & $\begin{array}{l}\text { Precip. } \\
\text { \% change } \\
\text { relative to historic) }\end{array}$ & $\begin{array}{l}\text { Evap. } \\
(\% \text { change } \\
\text { relative to historic) })\end{array}$ & $\begin{array}{l}\text { Runoff } \\
\text { (\% change } \\
\text { relative to historic) }\end{array}$ & $\begin{array}{l}\text { Runoff Ratio } \\
\text { relative to historic) }\end{array}$ & $\begin{array}{l}\text { Temp } \\
\left({ }^{\circ} \mathrm{C} \text { relative to }\right. \\
\text { historic) }\end{array}$ \\
\hline HISTORIC & $354 \mathrm{~mm} / \mathrm{yr}$. & $309 \mathrm{~mm} / \mathrm{yr}$. & $45.2 \mathrm{~mm} / \mathrm{yr}$. & $12.8 \%$ & $10.5^{\circ} \mathrm{C}$ \\
B1/PER 1 & $360(+1 \%)$ & $315(+2 \%)$ & $45.0(0 \%)$ & $12.5(-2 \%)$ & $11.8\left(+1.3^{\circ} \mathrm{C}\right)$ \\
B1/PER 2 & $351(-1 \%)$ & $310(0 \%)$ & $41.8(-7 \%)$ & $11.9(-7 \%)$ & $12.6\left(+2.1^{\circ} \mathrm{C}\right)$ \\
B1/PER 3 & $351(-1 \%)$ & $309(0 \%)$ & $41.6(-8 \%)$ & $11.8(-8 \%)$ & $13.2\left(+2.7^{\circ} \mathrm{C}\right)$ \\
A2/PER 1 & $351(-1 \%)$ & $307(-1 \%)$ & $44.6(-1 \%)$ & $12.7(-1 \%)$ & $11.8\left(+1.2^{\circ} \mathrm{C}\right)$ \\
A2/PER 2 & $348(-2 \%)$ & $305(-1 \%)$ & $42.7(-6 \%)$ & $12.2(-5 \%)$ & $13.1\left(+2.6^{\circ} \mathrm{C}\right)$ \\
A2/PER 3 & $347(-2 \%)$ & $306(-1 \%)$ & $40.3(-11 \%)$ & $11.6(-10 \%)$ & $14.9\left(+4.4^{\circ} \mathrm{C}\right)$ \\
\hline
\end{tabular}

Table 3. Percentage of annual precipitation, evaporation, runoff, and runoff ratio for simulations in which winter (Oct-March) and summer (April-Sep) precipitation was alternately increased and decreased by $10 \%$ relative to the unperturbed base run.

\begin{tabular}{lllll}
\hline Change & Precipitation & Evaporation & Runoff & Runoff Ratio \\
\hline Winter $+10 \%$ & $105.0 \%$ & $103.7 \%$ & $115.0 \%$ & $109.4 \%$ \\
Winter $-10 \%$ & $94.8 \%$ & $96.0 \%$ & $87.2 \%$ & $92.2 \%$ \\
Summer $+10 \%$ & $104.7 \%$ & $104.3 \%$ & $108.5 \%$ & $103.1 \%$ \\
Summer $-10 \%$ & $95.0 \%$ & $95.0 \%$ & $93.0 \%$ & $97.7 \%$ \\
\hline
\end{tabular}

was the same as the average over the 50-year base period. This contrasts with Christensen et al. (2004) who used initial storage equal to the 1970 historic (actual) level.

\subsubsection{Storage}

Figure 8 shows average January 1 storage as a function of streamflow for each streamflow ensemble by period and scenario, as well as the streamflow and storage from Christensen et al. (2004), and storage-streamflow combinations from runs in which the base run streamflows were altered in increments of $10 \%$ from $-50 \%$ to $+50 \%$. The black dotted line shows that for a given streamflow sequence an increase or decrease of $10 \%$ in average streamflow is magnified into an increase or decrease of about $20 \%$ in average basin storage, and that a $20 \%$ change in streamflow results in roughly a $40 \%$ storage change. Results for each of the ensembles generated for this study follow this general pattern, although the sensitivities when averaged across ensembles are somewhat different than implied by the dashed line. Again, this is primarily a result of the base run having low average storage relative to its average streamflow (because of the low flows early in the sequence).

Although average streamflow in period 1 for both SRES scenarios is less than the base run, CRRM simulates slight ensemble average reservoir level increases of $4(-20,23)$ and $1(-13,15) \%$ for A2 and B1, respectively (Table 4$)$. In period 2 , streamflow changes of $-6(-14,8)$ and $-7(-15$, $0) \%$ drive January 1 storage changes of $-1(-40,22)$ and
Streamflow vs. Storage (SRES A2 \& B1, ACPI, BASE)

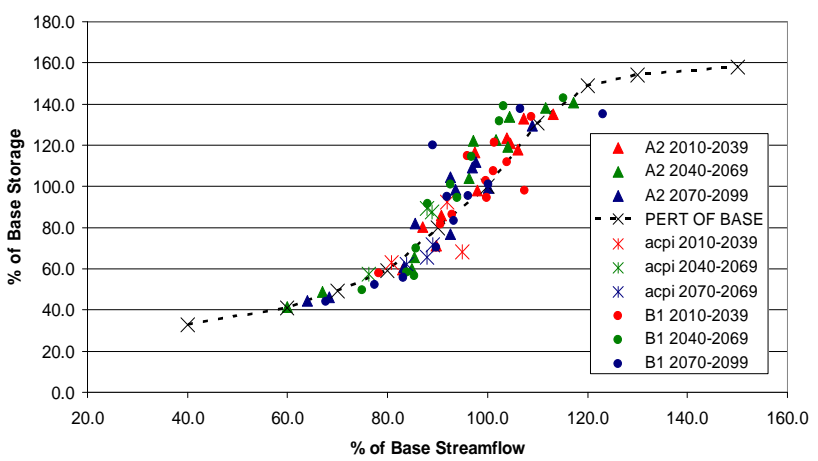

Fig. 8. Average January 1 total basin storage by period for A2 (triangles), B1 (circles), previous ACPI study (stars), and perturbation of base run (black dotted line).

$-5(-42,32) \%$ for the A2 and B1 scenarios, respectively, while period 3 changes in streamflow of $-11(-16,-1)$ and $-8(-18,-1) \%$ drive storage changes of $-13(-39$, $+9)$ and $-10(-46,+20) \%$ for A2 and B1, respectively (Tables A.3 and A.4 provide results for individual ensemble members). It should be noted that there are many nonlinearities in the relationship between reservoir performance and inflows (and in fact, the clustering of the points in Fig. 8 around the dashed line is somewhat tighter than one might expect for this reason). For example, in Fig. 8, the B1 period 3 simulation (IPSL) in which $90 \%$ of base streamflow drives 


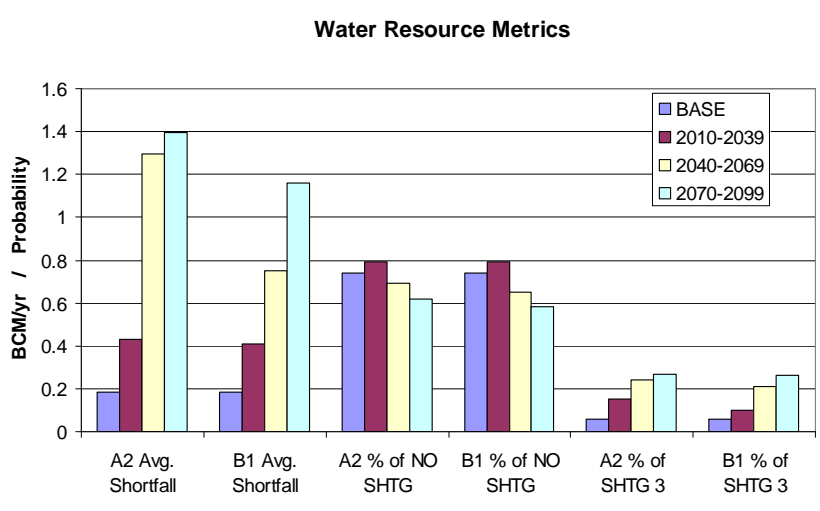

Fig. 9. Average shortfall per year, percentage of years with no shortfall and percentage of years with a level 3 shortage for the base run and SRES A2 and B1 scenarios.

reservoir storage of $120 \%$ of base is a function of very high initial reservoir levels ( $>56 \mathrm{BCM}$ ) and very high early period streamflow and low late period streamflow. Another outlier in Fig. 8 is the B1, period 1 simulation (MRI) in which $110 \%$ of base streamflow drives a storage reduction. This is a result of MRI having very low streamflow prior to 2010 and a result, total initial reservoir storage of only $17 \mathrm{BCM}$.

Although these results seem inconsistent with the greater storage reductions predicted by Christensen et al. (2004), they are within the same range of sensitivity. Christensen et al. (2004) predicted streamflow reductions at the high end of those simulated for individual ensemble members for this study, and as can be seen in Fig. 8, storage reductions in these ensemble members match those of the 2004 study.

\subsubsection{Delivery compliance}

Water deliveries are dependent on the storage in Lake Mead; level one shortages are imposed (see Sect. 2.3 for amounts and to which users) when Lake Mead drops below an elevation of $327.66 \mathrm{~m}$, level two shortages are imposed at an elevation of $320.04 \mathrm{~m}$, and level three at $312.42 \mathrm{~m}$. If need be, deliveries are decreased further to ensure that the elevation of Lake Mead does not drop below the SNWA's intake at $304.80 \mathrm{~m}$ elevation.

Figure 9 shows the average shortage per year, the percentage of years with no shortages, and the percentage of years with level three shortages for the 1950-1999 "base" run and for the SRES A2 and B1 ensemble averages for periods 1-3. The base run has delivery shortages in $26 \%$ of years. In reality, there have not yet been shortages, but they are simulated in the base run here because we force CRRM with 19501999 streamflow and year 2000 demands. Shortages are simulated in the base run between the late 50 s and mid 70s, while in real operations upper basin demands were lower and there were no shortages. The A2 and B1 scenarios both have shortages in 21 (A2; 1, 41, B1; 4, 26)\% of years in period 1,31
$(0,80)$ and $35(0,63) \%$ of years in period 2 , and $38(6,86)$ and $42(6,71) \%$ in period 3 .

Level three shortages beginning at $740 \mathrm{MCM} / \mathrm{yr}$ are initially imposed when Lake Mead drops below $312.42 \mathrm{~m}$, but are allowed to increase up to the entirety of the Lower Basin and Mexico's demand to protect a Lake Mead elevation of $304.80 \mathrm{~m}$. The probability of these shortages, along with the average shortage amount (Fig. 9), are not influenced much by the nuances of the reservoir model (initial storage, streamflow sequence, etc.). They are also likely to have considerable socio-economic effect within the basin. Level three shortages are imposed in the base run in $5 \%$ of years, and in $11(0,30)$ and $10(0,15) \%$ in period one, $24(0,45)$ and $27(0,45) \%$ in period two, and $27(4,27)$ and $26(0,33) \%$ in period three for the SRES A2 and B1 ensemble averages, respectively.

The shortfall per year (BCM/yr) is derived by dividing the total shortfall in each period by the number of years in which any shortage delivery is imposed. It is a somewhat redundant metric because it is related to the number of level three shortages, however it is important to differentiate between long modest shortfalls and short intense ones. The average shortage in the base run was $0.73 \mathrm{BCM}$, and $2.1(0.6,2.2)$ and $2.0(0.6,2.4) \mathrm{BCM} / \mathrm{yr}$ in period one for the $\mathrm{A} 2$ and $\mathrm{B} 1$ scenario, respectively. Average shortfalls in period two were $4.2(0,3.5)$ and $2.1(0,2.4) \mathrm{BCM} / \mathrm{yr}$, and $3.7(0.6,3.9)$ and $2.8(0.7,3.8) \mathrm{BCM}$ in period three for $\mathrm{A} 2$ and $\mathrm{B} 1$, respectively. Although there seems to be a lack of correlation between streamflow and average shortage (e.g. SRES A2, period 2 has greater streamflow than B2 period 3, yet higher average shortage), this is entirely an artifact of averaging across ensembles. Tables A.3 and A.4 summarize individual GCM run results.

\subsubsection{Hydropower generation}

Hydropower generation is a function of head (height of water surface above tailwater elevation) and discharge (volume per unit time) passing through a turbine. Because of the sequencing of the base run streamflow and its bias towards lower storage (i.e. head) for a given inflow, it generates less hydropower than the period one A2 and B1 average (Fig. 10). The average energy generated in the base run is $8480 \mathrm{GW}$ $\mathrm{h} / \mathrm{yr}$, while in period one the A2 scenario average generates $8600(10100,6470) \mathrm{GW}-\mathrm{h} / \mathrm{yr}$, and in the B2 scenario average $8530(9670,8220) \mathrm{GW}-\mathrm{h} / \mathrm{yr}$. In period two, the A2 average is $7630(10800,4470)$, and the B1 average is 7560 (10 330, 4650) GW-h/yr, while in period three A2 is 6900 $(8960,4560)$ and B1 is $7130(8840,4670) \mathrm{GW}-\mathrm{h} / \mathrm{yr}$. The reduction of hydropower production from period 1 to period 3 is $20 \%$ in the A2 scenario and $16 \%$ in the B1 scenario, both of which are about twice the corresponding streamflow reduction percentages. 
Table 4. Streamflow at Imperial Dam, AZ (BCM/yr), average January 1 total basin storage (BCM), release from Glen Canyon Dam $(\mathrm{BCM} / \mathrm{yr})$, annual energy production $(\mathrm{GW}-\mathrm{h} / \mathrm{yr})$, percentage of years with no delivery shortages, average annual delivery shortage (BCM/yr), average annual CAP delivery shortage (BCM/yr), and annual average MWD delivery shortage (BCM/yr).

\begin{tabular}{lcccccccc}
\hline BASE & $\begin{array}{c}\text { Imperial Naturalized } \\
\text { Flow }\end{array}$ & $\begin{array}{c}\text { Avg. } \\
\text { Storage. }\end{array}$ & G.C. Rls. & $\begin{array}{c}\text { Avg. } \\
\text { Energy }\end{array}$ & $\begin{array}{c}\text { \% Full } \\
\text { Deliveries }\end{array}$ & $\begin{array}{c}\text { Avg. Annual } \\
\text { Shortage }\end{array}$ & $\begin{array}{c}\text { Avg. Annual } \\
\text { CAP Shortage }\end{array}$ & $\begin{array}{c}\text { Avg. Annual } \\
\text { MWD Shortage }\end{array}$ \\
\hline $1950-1999$ & 19.7 & 41.8 & 11.8 & 8478.4 & 73.7 & 0.19 & 0.14 & 0.00 \\
\hline A2 & & & & & & & & \\
$2010-2039$ & 19.4 & 43.3 & 11.8 & 8596.9 & 78.9 & 0.43 & 0.17 \\
2040-2069 & 18.5 & 41.6 & 10.9 & 7630.1 & 69.1 & 1.30 & 0.37 \\
$2070-2099$ & 17.6 & 36.6 & 10.4 & 6904.8 & 62.3 & 1.39 & 0.41 & 0.11 \\
\hline B1 & & & & & & & 0.12 \\
$2010-2039$ & 19.4 & 42.2 & 11.7 & 8532.6 & 78.9 & 0.41 & 0.16 \\
$2040-2069$ & 18.4 & 39.9 & 11.0 & 7559.9 & 65.0 & 0.75 & 0.30 \\
$2070-2099$ & 18.3 & 37.6 & 10.9 & 7127.6 & 58.4 & 1.16 & 0.04 \\
\hline
\end{tabular}

\subsubsection{Glen Canyon Dam and Mexico release}

The Colorado River Compact mandates a 10 year moving average release of $10.2 \mathrm{BCM} / \mathrm{yr}$ from the Upper Basin to the Lower Basin and an annual release of 1.9 BCM (1.5 MAF) from the United States to Mexico. Figure 10 and Table 4 report the detailed results, but in general releases from Glen Canyon Dam are 1 (A2: $+1,-1, \mathrm{~B} 1:+6,-6) \%$ less (both $\mathrm{B} 1$ and A2) in period one than in the historical run and 7 $(+6,-21)$ and $8(+10,-21) \%$ lower in period 2 for B1 and A2, respectively. Period 3 has an $8(+2,-22) \%$ reduction in Glen Canyon releases in the B1 scenario, and a $12(-4$, $-30) \%$ reduction in A2. Although the compact requires the $10.2 \mathrm{BCM} / \mathrm{yr}$ release to be made on a 10 year moving average, current basin operations dictate that this release is made annually. The Glen Canyon release drops below 10.2 BCM in $24 \%$ of years in the base run, and 28,35 , and $35 \%$ of years for the B1 scenario in periods $1-3$, respectfully. The Glen Canyon release drops below 10.2 BCM/yr in 28, 34, and $44 \%$ of years in the A2 scenario for periods 1-3, respectfully.

Mexico is allocated $17 \%$ of the level one through three shortage amount, so the amount of years in which the Lower Basin delivery to Mexico drops below 1.9 BCM is essentially the same as the percentage of years in which any shortages are imposed (see Sect. 3.5.2). The average delivery to Mexico in the base run is $1.8 \mathrm{BCM} / \mathrm{yr}$, while the $\mathrm{B} 1$ scenario average annual deliveries drop to 1.78 (1.75, 1.83), 1.72 (1.65, $1.81), 1.65$ (1.40, 1.81) BCM for periods $1-3$ respectfully. In periods $1-3$ of the $\mathrm{A} 2$ scenario, average annual deliveries are 1.78 (1.72, 1.89), 1.63 (1.45, 1.87), 1.62 (1.48, 1.80) BCM, respectfully.

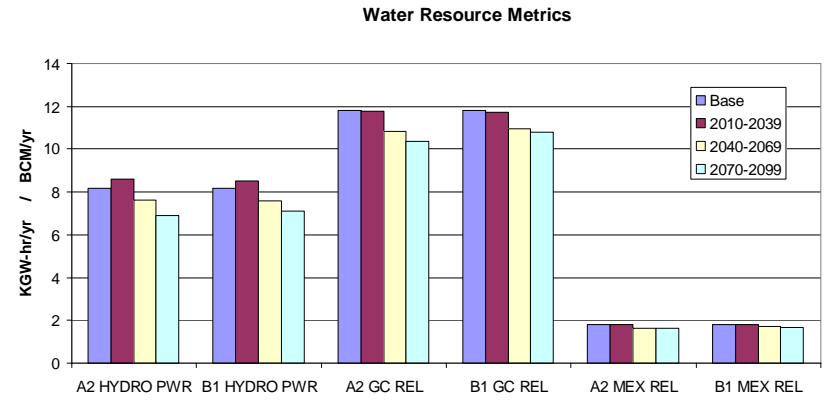

Fig. 10. Average hydropower production $(\mathrm{KGW}-\mathrm{h} / \mathrm{yr})$, average annual release from Glen Canyon Dam (BCM/yr), and average annual release to Mexico (BCM/yr) for the base run and period 1-3 for the SRES A2 and B1 scenarios.

\section{Conclusions}

As compared with earlier studies of climate sensitivity of $\mathrm{CRB}$ water resources to climate change, we have assessed in detail the implications of eleven downscaled IPCC climate model scenarios and two emissions scenarios, each one of which constitutes an ensemble member. Therefore, we are able to evaluate the range of possible consequences as represented by the different models and emissions scenarios, including "consensus" (mean) results, and measures of variability, in particular, the lower and upper quartiles. In this respect, this study is the most comprehensive to date of the implications of climate change on the Colorado River reservoir system.

As in essentially all previous studies, average annual temperatures over the CRB increase with time, not only in the ensemble mean, but for all individual climate models and time period. With the exception of the early part of the century when the A2 and B1 emission scenarios are similar and 
natural variability can dominate the emissions signal, temperatures are greater for the $\mathrm{A} 2$ emission scenario than for B1. Average temperature increases for the period 2070-2099 are $2.75^{\circ} \mathrm{C}$ (with a range of $+/-1.0^{\circ} \mathrm{C}$ ) for the $\mathrm{B} 1$ scenario and $4.35^{\circ} \mathrm{C}\left(+/-1.5^{\circ} \mathrm{C}\right)$ for the $\mathrm{A} 2$ scenario.

While all models agree with respect to the direction of temperature changes, there is considerable variability in the magnitude, direction, and seasonality of projected precipitation changes. Averaged over models, annual precipitation changes are quite small - a maximum change (decrease) of $2 \%$ for period 2 and 3 for the A2 emissions scenario. The variability across models is, in general, much larger than the annual change. More apparent in the ensemble means are shifts in seasonality of precipitation, which, in the ensemble mean, all show a shift towards more winter and less summer precipitation. Because winter precipitation (especially in the upper basin) contributes proportionately more to runoff than does summer precipitation, these shifts tend to counteract reductions in annual runoff that otherwise would result from increased temperatures (hence evapotranspiration) This shift toward winter precipitation is prevalent in the ensemble average for all periods and scenarios and is most pronounced for the basin upstream of Lees Ferry. Nonetheless, while this shift reduces the effect of increased temperatures on runoff, it does not reverse them, and in the ensemble mean streamflow decreases for all periods on both emissions scenarios.

Runoff changes are driven by combined effects of temperature and precipitation changes and their seasonality. In the ensemble means, runoff declines for all periods and both emissions scenarios, with the greatest changes occurring in period 3 for the A2 emissions scenario. Most (ensemble mean) changes in annual streamflow at Lees Ferry are in the single digit percentages, ranging up to an $11 \%$ streamflow reduction for emissions scenario A2 in period 3. The range of changes across ensembles is quite large, however, for instance for emissions scenario $\mathrm{A} 2$ in period 3 the range is from -37 to $+11 \%$.

The runoff changes we project are considerably less in the ensemble mean than those inferred for the U.S. Southwest in recent studies by Milly et al. (2005) and Seager et al. (2007). Both these studies use IPCC AR4 ensembles, but are based on runoff (or equivalently, atmospheric convergence) simulated directly by GCMs over the region. Aside from differences in the specific locale and the GCMs analyzed (which we do not believe account for the bulk of the differences), the smaller runoff sensitivity to climate changes in this study appears to be traceable to the sensitivity of annual evapotranspiration to seasonal shifts in runoff and evapotranspiration timing. In the ensemble mean, we find that projected annual precipitation changes are small, hence runoff reductions should be attributable mostly to differences in evapotranspiration. Our hydrological model operates at considerably higher spatial resolution than the native resolution of the GCMs, hence is better able to resolve the interactions of elevation with seasonally varying evaporative demands. In short, there is a negative feedback between increased temperature, which shifts snowmelt timing, and hence soil moisture, earlier in the year, when evaporative demands are lower, and in turn reduces runoff and ET sensitivity to increased temperature. This effect is especially important over the relatively small high elevation headwaters area where most of the CRB's runoff is generated. The GCMs are not able to resolve this effect well as their coarse spatial resolution precludes their representing high elevation headwater areas. However, understanding of the nature of this feedback, and the extent to which it explains differences in sensitivities between this study, and Milly et al. (2005) and Seager et al. (2007) is a topic of both scientific and practical importance that deserves further attention.

Due to the fragile equilibrium of the managed water resources of the system, any decrease in streamflow results in storage and hydropower decreases, compact violations, and delivery reductions. There are many nonlinearities in the reservoir system response to streamflow, which in general are reflected in amplifications of the range of responses across the ensemble members (models). In general, changes in total basin storage amplify changes in streamflow, and very roughly, for modest (e.g. single digit) percentage changes in streamflow, the storage changes (also expressed as percentages) are about double.

Although our results show somewhat smaller (ensemble mean) reductions in runoff over the next century than in previous studies (Christensen et al, 2004 in particular), the reservoir system simulations show nonetheless that supply may be reduced below current demand which in turn will cause considerable degradation of system performance. Reductions in total basin storage, Compact mandated deliveries, and hydropower production increase throughout the century, and are larger in the A2 than the B1 scenario. Although not analyzed explicitly in this paper (see Christensen (2004) for details) increasing Upper Basin demands towards their full entitlement will further exacerbate these reservoir performance issues.

Due to the already large storage to inflow ratio of the CRB, neither increases in reservoir capacity nor changes in operating policies are likely to mitigate these stresses substantially. Clearly depletions (including reservoir evaporation) cannot exceed supply in the long term. Furthermore, due to the high coefficient of variation of annual streamflows in the CRB, and notwithstanding the system's large reservoir storage, the system is likely to become more susceptible to long term sustained droughts if the excess of supply over demand is reduced, as is suggested by the ensemble means in our study. 


\section{Appendix A}

\section{Detailed downscaled GCM results and derived (VIC hydrologic model) variables}

Table A1. a) 1950-1999 "base" mean annual precipitation, evaporation, runoff, temperature, soil moisture, SWE, and runoff ratio in mm/yr and mm; b), c), d) Period 1-3 SRES A2 mean annual precipitation, evaporation, runoff, temperature, soil moisture, snow water equivalent (SWE), and runoff ratio (ROR) (all as percentages of 1950-1999 base, except temperature which is in ${ }^{\circ} \mathrm{C}$ change relative to base).

\begin{tabular}{|c|c|c|c|c|c|c|c|}
\hline \multirow[t]{2}{*}{ a) } & \multicolumn{7}{|l|}{ 1950-1999 } \\
\hline & PRECIP (mm/yr) & $\operatorname{EVAP}(\mathrm{mm} / \mathrm{yr})$ & RUNOFF (mm/yr) & TEMPERATURE $\left({ }^{\circ} \mathrm{C}\right)$ & SOIL MOISTURE (mm) & SWE (mm/yr) & $\operatorname{ROR}(\%)$ \\
\hline BASE & 354.4 & 309.0 & 45.2 & 10.5 & 286.1 & 11.1 & 12.8 \\
\hline \multirow[t]{2}{*}{ b) } & A2 2010-2039 & & & & & & \\
\hline & $\%$ PRECIP & $\%$ EVAP & $\%$ RUNOFF & $\Delta$ TEMPERATURE & $\%$ SOIL MOISTURE & $\%$ SWE & $\%$ ROR \\
\hline CNRM & 97.86 & 98.63 & 97.82 & 1.07 & 99.22 & 93.13 & 99.96 \\
\hline CSIRO & 101.37 & 101.22 & 98.49 & 0.94 & 98.81 & 86.13 & 97.15 \\
\hline GFDL & 92.16 & 92.92 & 91.22 & 1.45 & 97.86 & 94.96 & 98.98 \\
\hline GISS & 102.99 & 101.43 & 107.03 & 0.95 & 102.16 & 92.82 & 103.92 \\
\hline HADCM3 & 100.78 & 101.55 & 93.69 & 1.41 & 98.36 & 73.78 & 92.97 \\
\hline INMCM & 105.16 & 104.81 & 107.59 & 1.70 & 102.41 & 91.58 & 102.31 \\
\hline IPSL & 101.29 & 100.75 & 104.56 & 1.49 & 99.63 & 90.05 & 103.23 \\
\hline MIROC & 93.61 & 94.96 & 85.62 & 1.82 & 94.59 & 63.65 & 91.47 \\
\hline MPI & 90.65 & 91.73 & 83.53 & 1.24 & 94.80 & 75.29 & 92.14 \\
\hline MRI & 96.71 & 96.89 & 101.54 & 0.84 & 100.15 & 100.99 & 104.99 \\
\hline PCM & 107.01 & 106.48 & 114.48 & 0.63 & 103.01 & 93.96 & 106.98 \\
\hline AVG & 99.054 & 99.213 & 98.688 & 1.230 & 99.181 & 86.939 & 99.464 \\
\hline \multirow[t]{2}{*}{ c) } & A2 2040-2069 & & & & & & \\
\hline & $\%$ PRECIP & $\%$ EVAP & $\%$ RUNOFF & $\Delta$ TEMPERATURE & \% SOIL MOISTURE & $\%$ SWE & $\%$ ROR \\
\hline CNRM & 79.16 & 82.03 & 60.74 & 2.35 & 89.07 & 72.01 & 76.73 \\
\hline CSIRO & 97.65 & 98.64 & 97.29 & 1.87 & 97.58 & 82.96 & 99.63 \\
\hline GFDL & 93.43 & 93.78 & 86.87 & 3.18 & 95.23 & 71.38 & 92.98 \\
\hline GISS & 106.66 & 107.02 & 113.24 & 1.75 & 104.37 & 106.13 & 106.16 \\
\hline HADCM3 & 108.94 & 108.95 & 107.90 & 2.83 & 102.78 & 83.89 & 99.05 \\
\hline INMCM & 113.39 & 112.66 & 118.25 & 3.14 & 104.01 & 80.24 & 104.29 \\
\hline IPSL & 97.75 & 97.76 & 101.03 & 3.27 & 98.37 & 81.36 & 103.36 \\
\hline MIROC & 82.40 & 85.00 & 65.57 & 3.65 & 87.81 & 48.12 & 79.57 \\
\hline MPI & 95.38 & 96.62 & 86.18 & 2.59 & 96.45 & 66.72 & 90.36 \\
\hline MRI & 98.57 & 99.05 & 96.05 & 1.94 & 98.44 & 92.04 & 97.44 \\
\hline PCM & 105.66 & 104.92 & 104.91 & 1.61 & 102.03 & 83.22 & 99.29 \\
\hline AVG & 98.090 & 98.767 & 94.367 & 2.561 & 97.829 & 78.917 & 95.351 \\
\hline \multirow[t]{2}{*}{ d) } & A2 2070-2099 & & & & & & \\
\hline & $\%$ PRECIP & $\%$ EVAP & $\%$ RUNOFF & $\triangle$ TEMPERATURE & $\%$ SOIL MOISTURE & $\%$ SWE & $\%$ ROR \\
\hline CNRM & 91.98 & 93.48 & 69.60 & 4.40 & 91.50 & 58.08 & 75.67 \\
\hline CSIRO & 97.96 & 99.17 & 90.82 & 3.32 & 95.71 & 69.07 & 92.72 \\
\hline GFDL & 93.75 & 95.56 & 84.19 & 5.38 & 95.11 & 52.46 & 89.80 \\
\hline GISS & 88.34 & 88.88 & 85.76 & 3.33 & 96.31 & 84.84 & 97.07 \\
\hline HADCM3 & 112.84 & 114.48 & 100.24 & 4.88 & 103.88 & 52.84 & 88.83 \\
\hline INMCM & 101.88 & 103.30 & 92.07 & 4.53 & 97.33 & 59.77 & 90.37 \\
\hline IPSL & 93.45 & 94.20 & 90.32 & 5.63 & 94.98 & 44.94 & 96.64 \\
\hline MIROC & 84.35 & 87.54 & 62.76 & 6.06 & 87.51 & 33.52 & 74.40 \\
\hline MPI & 104.52 & 104.57 & 98.75 & 4.51 & 99.15 & 58.29 & 94.48 \\
\hline MRI & 98.71 & 98.30 & 94.14 & 3.05 & 96.39 & 83.36 & 95.37 \\
\hline PCM & 110.71 & 111.03 & 110.77 & 2.77 & 102.73 & 81.13 & 100.05 \\
\hline AVG & 98.046 & 99.136 & 89.038 & 4.350 & 96.419 & 61.663 & 90.492 \\
\hline
\end{tabular}


Table A2. a) 1950-1999 (base) mean annual precipitation, evaporation, runoff, temperature, soil moisture, snow water equivalent (SWE), and runoff ratio (ROR) in $\mathrm{mm} / \mathrm{yr}$ and $\mathrm{mm}\left({ }^{\circ} \mathrm{C}\right.$ for temperature). b, c, d) Period 1-3 SRES B1 precipitation, evaporation, runoff, temperature, soil moisture, SWE, and runoff ratio as percentage of 1950-1999 base.

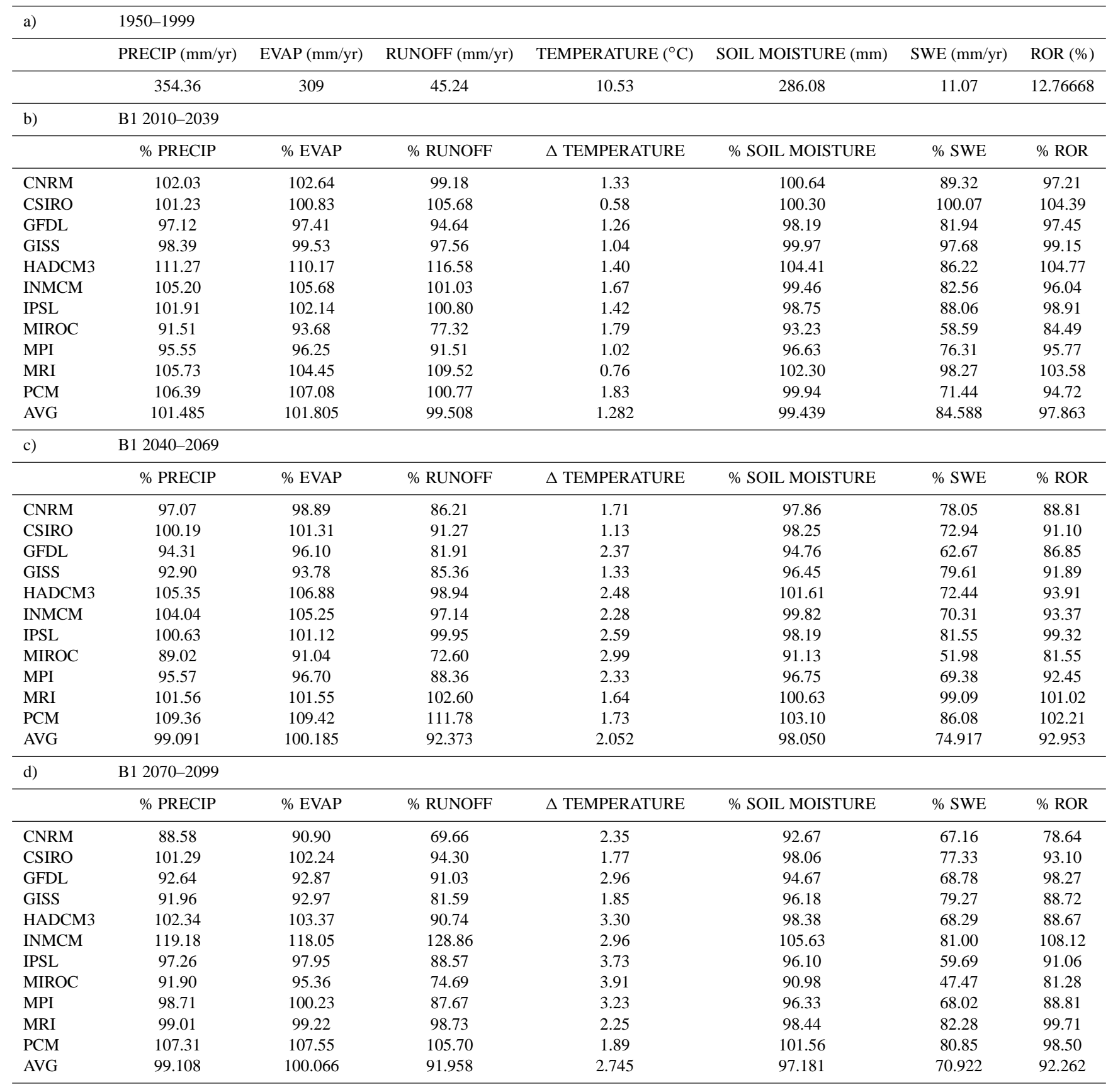


Table A3. Average annual naturalized flow at Imperial Dam (BCM/yr), average total simulated basin storage (BCM), annual release from Glen Canyon Dam (BCM/yr), average annual energy production (GW-h/yr), percent of years with full deliveries (\%), average annual delivery shortfall (BCM/yr), average annual CAP shortfall (BCM/yr), and average annual MWD shortfall (BCM/yr) for a) 1950-1999 base run and b), c), d) for SRES A2 scenario for Periods 1-3.

\begin{tabular}{|c|c|c|c|c|c|c|c|c|}
\hline \multirow[t]{2}{*}{ a) } & \multicolumn{8}{|l|}{ 1950-1999 } \\
\hline & $\begin{array}{l}\text { Imperial Naturalized } \\
\text { Flow (BCM/yr) }\end{array}$ & $\begin{array}{l}\text { Avg. Storage. } \\
(\mathrm{BCM})\end{array}$ & $\begin{array}{l}\text { G.C. Rls. } \\
\text { (BCM/yr) }\end{array}$ & $\begin{array}{l}\text { Avg. Energy } \\
(\mathrm{GW}-\mathrm{h} / \mathrm{yr})\end{array}$ & $\begin{array}{l}\% \text { Full Deliveries } \\
(\%)\end{array}$ & $\begin{array}{l}\text { Avg. Annual } \\
\text { Shortage } \\
(\mathrm{BCM} / \mathrm{yr})\end{array}$ & $\begin{array}{l}\text { Avg. Annual CAP } \\
\text { Shortage } \\
(\mathrm{BCM} / \mathrm{yr})\end{array}$ & $\begin{array}{l}\text { Avg. Annual MWD } \\
\text { Shortage } \\
(\mathrm{BCM} / \mathrm{yr})\end{array}$ \\
\hline & 19.7 & 41.8 & 11.8 & 8478 & 73.7 & 0.19 & 0.14 & 0 \\
\hline \multirow[t]{2}{*}{ b) } & \multicolumn{8}{|l|}{ A2 2010-2039 } \\
\hline & $\begin{array}{l}\text { Imperial Naturalized } \\
\text { Flow (BCM/yr) }\end{array}$ & $\begin{array}{l}\text { Avg. Storage } \\
(\mathrm{BCM})\end{array}$ & $\begin{array}{l}\text { G.C. Rls. } \\
\text { (BCM/yr) }\end{array}$ & $\begin{array}{l}\text { Avg. Energy } \\
(\mathrm{GW}-\mathrm{h} / \mathrm{yr})\end{array}$ & $\begin{array}{l}\% \text { Full Deliveries } \\
(\%)\end{array}$ & $\begin{array}{l}\text { Avg. Annual } \\
\text { Shortage } \\
(\mathrm{BCM} / \mathrm{yr})\end{array}$ & $\begin{array}{l}\text { Avg. Annual CAP } \\
\text { Shortage } \\
(\mathrm{BCM} / \mathrm{yr})\end{array}$ & $\begin{array}{l}\text { Avg. Annual MWD } \\
\text { Shortage } \\
(\mathrm{BCM} / \mathrm{yr})\end{array}$ \\
\hline $\mathrm{cnrm}$ & 19.2 & 48.7 & 12.0 & 9812 & 99.2 & 0.00 & 0.00 & 0.00 \\
\hline cisro & 19.3 & 41.0 & 11.4 & 8204 & 81.7 & 0.11 & 0.09 & 0.00 \\
\hline gfdl & 17.9 & 35.8 & 10.7 & 7865 & 82.5 & 0.10 & 0.08 & 0.00 \\
\hline giss & 20.9 & 49.3 & 13.0 & 9909 & 88.6 & 0.16 & 0.08 & 0.01 \\
\hline hadem 3 & 17.7 & 29.8 & 10.2 & 5483 & 41.4 & 1.36 & 0.54 & 0.12 \\
\hline inmcm & 21.2 & 55.5 & 13.4 & 10716 & 95.8 & 0.02 & 0.02 & 0.00 \\
\hline ipsl & 20.6 & 50.5 & 12.4 & 9823 & 99.7 & 0.00 & 0.00 & 0.00 \\
\hline miroc & 17.2 & 33.5 & 10.2 & 6468 & 58.3 & 1.30 & 0.42 & 0.11 \\
\hline mpi & 16.4 & 24.9 & 9.4 & 4658 & 20.3 & 1.72 & 0.69 & 0.15 \\
\hline mri & 20.5 & 51.6 & 12.5 & 10139 & 100.0 & 0.00 & 0.00 & 0.00 \\
\hline $\mathrm{pcm}$ & 22.3 & 56.5 & 14.4 & 11489 & 100.0 & 0.00 & 0.00 & 0.00 \\
\hline AVG & 19.4 & 43.4 & 11.8 & 8597 & 78.9 & 0.43 & 0.17 & 0.04 \\
\hline \multirow[t]{2}{*}{ c) } & \multicolumn{8}{|l|}{ A2 2040-2069 } \\
\hline & $\begin{array}{l}\text { Imperial Naturalized } \\
\text { Flow (BCM/yr) }\end{array}$ & $\begin{array}{l}\text { Avg. Storage } \\
(\mathrm{BCM})\end{array}$ & $\begin{array}{l}\text { G.C. Rls. } \\
\text { (BCM/yr) }\end{array}$ & $\begin{array}{l}\text { Avg. Energy } \\
(\mathrm{GW}-\mathrm{h} / \mathrm{yr})\end{array}$ & $\begin{array}{l}\% \text { Full Deliveries } \\
(\%)\end{array}$ & $\begin{array}{l}\text { Avg. Annual } \\
\text { Shortage } \\
(\mathrm{BCM} / \mathrm{yr})\end{array}$ & $\begin{array}{l}\text { Avg. Annual CAP } \\
\text { Shortage } \\
(\mathrm{BCM} / \mathrm{yr})\end{array}$ & $\begin{array}{l}\text { Avg. Annual MWD } \\
\text { Shortage } \\
(\mathrm{BCM} / \mathrm{yr})\end{array}$ \\
\hline $\mathrm{cnrm}$ & 11.8 & 17.3 & 5.5 & 1319 & 0.0 & 5.95 & 1.46 & 0.52 \\
\hline cisro & 19.1 & 51.0 & 11.6 & 9503 & 99.2 & 0.00 & 0.00 & 0.00 \\
\hline gfdl & 16.7 & 25.1 & 9.3 & 4467 & 28.9 & 1.98 & 0.67 & 0.15 \\
\hline giss & 22.0 & 57.7 & 13.4 & 10871 & 99.7 & 0.00 & 0.00 & 0.00 \\
\hline hadem 3 & 20.5 & 49.7 & 11.9 & 9432 & 100.0 & 0.00 & 0.00 & 0.00 \\
\hline inmcm & 23.1 & 58.8 & 14.2 & 11649 & 100.0 & 0.00 & 0.00 & 0.00 \\
\hline ipsl & 20.6 & 55.9 & 13.0 & 10798 & 100.0 & 0.00 & 0.00 & 0.00 \\
\hline miroc & 13.2 & 20.4 & 6.8 & 2436 & 12.2 & 4.85 & 1.28 & 0.46 \\
\hline mpi & 16.8 & 27.4 & 9.9 & 5465 & 36.9 & 1.08 & 0.48 & 0.08 \\
\hline mri & 19.0 & 43.5 & 11.2 & 8236 & 82.8 & 0.38 & 0.14 & 0.03 \\
\hline $\mathrm{pcm}$ & 20.1 & 51.2 & 12.0 & 9754 & 100.0 & 0.00 & 0.00 & 0.00 \\
\hline AVG & 18.5 & 41.6 & 10.8 & 7630 & 69.1 & 1.30 & 0.37 & 0.11 \\
\hline \multirow[t]{2}{*}{ d) } & \multicolumn{8}{|l|}{ A2 2070-2099 } \\
\hline & $\begin{array}{l}\text { Imperial Naturalized } \\
\text { Flow (BCM/yr) }\end{array}$ & $\begin{array}{l}\text { Avg. Storage } \\
(\mathrm{BCM})\end{array}$ & $\begin{array}{l}\text { G.C. Rls. } \\
\text { (BCM/yr) }\end{array}$ & $\begin{array}{l}\text { Avg. Energy } \\
(\mathrm{GW}-\mathrm{h} / \mathrm{yr})\end{array}$ & $\begin{array}{l}\% \text { Full Deliveries } \\
(\%)\end{array}$ & $\begin{array}{l}\text { Avg. Annual } \\
\text { Shortage } \\
(\mathrm{BCM} / \mathrm{yr})\end{array}$ & $\begin{array}{l}\text { Avg. Annual CAP } \\
\text { Shortage } \\
(\mathrm{BCM} / \mathrm{yr})\end{array}$ & $\begin{array}{l}\text { Avg. Annual MWD } \\
\text { Shortage } \\
(\mathrm{BCM} / \mathrm{yr})\end{array}$ \\
\hline $\mathrm{cnrm}$ & 13.5 & 19.3 & 6.5 & 2318 & 9.7 & 4.66 & 1.20 & 0.42 \\
\hline cisro & 18.3 & 32.1 & 10.7 & 6491 & 60.3 & 0.82 & 0.35 & 0.07 \\
\hline gfdl & 16.4 & 25.4 & 9.4 & 4559 & 28.9 & 1.76 & 0.66 & 0.15 \\
\hline giss & 16.9 & 34.2 & 10.4 & 7322 & 67.8 & 0.49 & 0.20 & 0.03 \\
\hline hadcm 3 & 19.2 & 46.7 & 11.4 & 9041 & 95.6 & 0.02 & 0.02 & 0.00 \\
\hline inmcm & 18.2 & 43.7 & 11.1 & 8529 & 94.4 & 0.03 & 0.03 & 0.00 \\
\hline ipsl & 18.5 & 41.2 & 11.0 & 8105 & 80.3 & 0.45 & 0.15 & 0.03 \\
\hline miroc & 12.6 & 18.6 & 6.4 & 1782 & 0.0 & 5.49 & 1.38 & 0.48 \\
\hline mpi & 19.8 & 41.5 & 11.7 & 7586 & 61.1 & 1.50 & 0.46 & 0.13 \\
\hline mri & 19.1 & 45.6 & 11.4 & 8961 & 88.1 & 0.12 & 0.08 & 0.01 \\
\hline $\mathrm{pcm}$ & 21.5 & 54.1 & 14.0 & 11259 & 98.9 & 0.01 & 0.00 & 0.00 \\
\hline AVG & 17.6 & 36.6 & 10.4 & 6905 & 62.3 & 1.40 & 0.41 & 0.12 \\
\hline
\end{tabular}


Table A4. Average annual naturalized flow at Imperial Dam (BCM/yr), average total simulated basin storage (BCM), annual release from Glen Canyon Dam (BCM/yr), average annual energy production (GW-h/yr), percent of years with full deliveries (\%), average annual delivery shortfall (BCM/yr), average annual CAP shortfall (BCM/yr), and average annual MWD shortfall (BCM/yr) for a) 1950-1999 base run and b), c), d) for SRES B1 scenario for Periods 1-3.

\begin{tabular}{|c|c|c|c|c|c|c|c|c|}
\hline \multirow[t]{2}{*}{ a) } & \multicolumn{8}{|l|}{ 1950-1999 } \\
\hline & $\begin{array}{l}\text { Imperial Naturalized } \\
\text { Flow }(\mathrm{BCM} / \mathrm{yr})\end{array}$ & $\begin{array}{l}\text { Avg. Storage } \\
(\mathrm{BCM})\end{array}$ & $\begin{array}{l}\text { G.C. Rls. } \\
(\mathrm{BCM} / \mathrm{yr})\end{array}$ & $\begin{array}{l}\text { Avg. Energy } \\
(\mathrm{GW}-\mathrm{h} / \mathrm{yr})\end{array}$ & $\begin{array}{l}\% \text { Full Deliveries } \\
(\%)\end{array}$ & $\begin{array}{l}\text { Avg. Annual } \\
\text { Shortage } \\
(\mathrm{BCM} / \mathrm{yr})\end{array}$ & $\begin{array}{l}\text { Avg. Annual CAP } \\
\text { Shortage } \\
(\mathrm{BCM} / \mathrm{yr})\end{array}$ & $\begin{array}{l}\text { Avg. Annual MWD } \\
\text { Shortage } \\
(\mathrm{BCM} / \mathrm{yr})\end{array}$ \\
\hline & 19.7 & 41.8 & 11.8 & 8478 & 73.7 & 0.19 & 0.14 & 0 \\
\hline \multirow[t]{2}{*}{ b) } & \multicolumn{8}{|l|}{ B1 2010-2039 } \\
\hline & $\begin{array}{l}\text { Imperial Naturalized } \\
\text { Flow }(\mathrm{BCM} / \mathrm{yr})\end{array}$ & $\begin{array}{l}\text { Avg. Storage } \\
(\mathrm{BCM})\end{array}$ & $\begin{array}{l}\text { G.C. Rls. } \\
(\mathrm{BCM} / \mathrm{yr})\end{array}$ & $\begin{array}{l}\text { Avg. Energy } \\
(\mathrm{GW}-\mathrm{h} / \mathrm{yr})\end{array}$ & $\begin{array}{l}\% \text { Full Deliveries } \\
(\%)\end{array}$ & $\begin{array}{l}\text { Avg. Annual } \\
\text { Shortage } \\
(\mathrm{BCM} / \mathrm{yr})\end{array}$ & $\begin{array}{l}\text { Avg. Annual CAP } \\
\text { Shortage } \\
(\mathrm{BCM} / \mathrm{yr})\end{array}$ & $\begin{array}{l}\text { Avg. Annual MWD } \\
\text { Shortage } \\
(\mathrm{BCM} / \mathrm{yr})\end{array}$ \\
\hline cnrm & 19.7 & 39.5 & 11.6 & 8215 & 89.4 & 0.22 & 0.10 & 0.02 \\
\hline cisro & 20.5 & 46.6 & 12.7 & 8989 & 69.4 & 0.35 & 0.19 & 0.02 \\
\hline gfdl & 18.3 & 36.2 & 11.1 & 7979 & 81.7 & 0.10 & 0.08 & 0.00 \\
\hline giss & 18.9 & 48.0 & 12.1 & 9670 & 95.8 & 0.02 & 0.02 & 0.00 \\
\hline hadcm 3 & 21.5 & 55.9 & 13.2 & 10791 & 100.0 & 0.00 & 0.00 & 0.00 \\
\hline inmcm & 19.7 & 43.0 & 11.6 & 8159 & 73.1 & 0.39 & 0.18 & 0.02 \\
\hline ipsl & 20.0 & 44.9 & 12.5 & 9484 & 89.2 & 0.06 & 0.05 & 0.00 \\
\hline miroc & 15.4 & 24.2 & 9.0 & 4290 & 20.6 & 2.30 & 0.76 & 0.20 \\
\hline mpi & 17.9 & 34.2 & 10.8 & 7691 & 74.7 & 0.14 & 0.11 & 0.00 \\
\hline mri & 21.2 & 41.0 & 12.6 & 8771 & 74.4 & 0.92 & 0.28 & 0.08 \\
\hline pcm & 20.0 & 50.7 & 12.2 & 9820 & 100.0 & 0.00 & 0.00 & 0.00 \\
\hline AVG & 19.4 & 42.2 & 11.7 & 8533 & 78.9 & 0.41 & 0.16 & 0.03 \\
\hline \multirow[t]{2}{*}{ c) } & \multicolumn{8}{|l|}{ B1 2040-2069 } \\
\hline & $\begin{array}{l}\text { Imperial Naturalized } \\
\text { Flow (BCM/yr) }\end{array}$ & $\begin{array}{l}\text { Avg. Storage } \\
\text { (BCM) }\end{array}$ & $\begin{array}{l}\text { G.C. Rls. } \\
(\mathrm{BCM} / \mathrm{yr})\end{array}$ & $\begin{array}{l}\text { Avg. Energy } \\
(\mathrm{GW}-\mathrm{h} / \mathrm{yr})\end{array}$ & $\begin{array}{l}\% \text { Full Deliveries } \\
(\%)\end{array}$ & $\begin{array}{l}\text { Avg. Annual } \\
\text { Shortage } \\
(\mathrm{BCM} / \mathrm{yr})\end{array}$ & $\begin{array}{l}\text { Avg. Annual CAP } \\
\text { Shortage } \\
(\mathrm{BCM} / \mathrm{yr})\end{array}$ & $\begin{array}{l}\text { Avg. Annual MWD } \\
\text { Shortage } \\
(\mathrm{BCM} / \mathrm{yr})\end{array}$ \\
\hline cnrm & 17.4 & 38.2 & 10.3 & 7565 & 78.1 & 0.33 & 0.15 & 0.02 \\
\hline cisro & 18.2 & 42.1 & 10.9 & 8589 & 97.8 & 0.01 & 0.01 & 0.00 \\
\hline gfdl & 16.5 & 24.4 & 9.9 & 4646 & 14.7 & 1.38 & 0.63 & 0.11 \\
\hline giss & 16.9 & 29.3 & 9.9 & 5607 & 42.2 & 1.47 & 0.52 & 0.12 \\
\hline hadem 3 & 19.1 & 47.9 & 11.3 & 9085 & 91.1 & 0.05 & 0.04 & 0.00 \\
\hline inmcm & 18.5 & 39.4 & 10.7 & 7430 & 69.4 & 0.36 & 0.20 & 0.02 \\
\hline ipsl & 20.2 & 55.1 & 12.6 & 10330 & 100.0 & 0.00 & 0.00 & 0.00 \\
\hline miroc & 14.8 & 20.7 & 8.4 & 2902 & 2.2 & 3.08 & 1.07 & 0.30 \\
\hline mpi & 16.8 & 23.7 & 9.4 & 4335 & 19.7 & 1.54 & 0.66 & 0.13 \\
\hline mri & 20.4 & 58.0 & 12.6 & 10580 & 100.0 & 0.00 & 0.00 & 0.00 \\
\hline $\mathrm{pcm}$ & 22.7 & 59.8 & 14.8 & 12091 & 100.0 & 0.00 & 0.00 & 0.00 \\
\hline AVG & 18.3 & 39.9 & 11.0 & 7560 & 65.0 & 0.75 & 0.30 & 0.06 \\
\hline \multirow[t]{2}{*}{ d) } & \multicolumn{8}{|l|}{ B1 2070-2099 } \\
\hline & $\begin{array}{l}\text { Imperial Naturalized } \\
\text { Flow }(\mathrm{BCM} / \mathrm{yr})\end{array}$ & $\begin{array}{l}\text { Avg. Storage } \\
(\mathrm{BCM})\end{array}$ & $\begin{array}{l}\text { G.C. Rls. } \\
(\mathrm{BCM} / \mathrm{yr})\end{array}$ & $\begin{array}{l}\text { Avg. Energy } \\
\text { (GW-h/yr) }\end{array}$ & $\begin{array}{l}\% \text { Full Deliveries } \\
(\%)\end{array}$ & $\begin{array}{l}\text { Avg. Annual } \\
\text { Shortage } \\
(\mathrm{BCM} / \mathrm{yr})\end{array}$ & $\begin{array}{l}\text { Avg. Annual CAP } \\
\text { Shortage } \\
(\mathrm{BCM} / \mathrm{yr})\end{array}$ & $\begin{array}{l}\text { Avg. Annual MWD } \\
\text { Shortage } \\
(\mathrm{BCM} / \mathrm{yr})\end{array}$ \\
\hline cnrm & 13.4 & 18.4 & 6.4 & 1877 & 0.0 & 4.70 & 1.28 & 0.43 \\
\hline cisro & 18.9 & 39.8 & 11.3 & 7947 & 75.0 & 0.15 & 0.12 & 0.00 \\
\hline gfdl & 18.4 & 34.7 & 11.1 & 6911 & 52.5 & 0.78 & 0.35 & 0.06 \\
\hline giss & 16.4 & 23.3 & 9.2 & 4074 & 13.9 & 2.15 & 0.81 & 0.19 \\
\hline hadcm 3 & 18.1 & 39.7 & 10.8 & 7084 & 65.8 & 1.01 & 0.35 & 0.08 \\
\hline inmcm & 24.3 & 56.5 & 14.8 & 11978 & 100.0 & 0.00 & 0.00 & 0.00 \\
\hline ipsl & 17.6 & 50.1 & 10.5 & 8813 & 94.2 & 0.23 & 0.06 & 0.02 \\
\hline miroc & 15.3 & 21.8 & 8.7 & 3464 & 8.9 & 2.99 & 0.96 & 0.26 \\
\hline mpi & 17.7 & 29.4 & 10.7 & 6533 & 50.3 & 0.65 & 0.32 & 0.04 \\
\hline mri & 19.7 & 42.3 & 12.1 & 8869 & 81.7 & 0.12 & 0.09 & 0.00 \\
\hline $\mathrm{pcm}$ & 21.0 & 57.5 & 13.2 & 10853 & 100.0 & 0.00 & 0.00 & 0.00 \\
\hline AVG & 18.3 & 37.6 & 10.8 & 7128 & 58.4 & 1.16 & 0.40 & 0.10 \\
\hline
\end{tabular}


Edited by: A. Bronstert

\section{References}

Brown, R. D.: Northern hemisphere snow cover variability and change, 1915-97, J. Climate, 13, 2339-2355, 2000.

Christensen, N. S., Wood, A. W., Voisin, N., Lettenmaier, D. P., and Palmer, R. N.: Effects of climate change on the hydrology and water resources of the Colorado River Basin, Climatic Change, 62, 337-363, 2004.

Delworth, T. L., Broccoli, A. J., Rosati, A., Stouffer, R. J., Balaji, V., Beesley, J. A., Cooke, W. F., Dixon, K. W., Dunne, J., Dunne, K. A., Durachta, J. W., Findell, K. L., Ginoux, P., Gnanadesikan, A., Gordon, C. T., Griffies, S. M., Gudgel, R., Harrison, M. J., Held, I. M., Hemler, R. S., Horowitz, L. W., Klein, S. A., Knutson, T. R., Kushner, P. J., Langenhorst, A. R., Lee, H. C., Lin, S. J., Lu, J., Malyshev, S. L., Milly, P. C. D., Ramaswamy, V., Russell, J., Schwarzkopf, M. D., Shevliakova, E., Sirutis, J. J., Spelman, M. J., Stern, W. F., Winton, M., Wittenberg, A. T., Wyman, B., Zeng, F., and Zhang, R.: GFDL's CM2 global coupled climate models. Part I: Formulation and simulation characteristics, J. Climate, 19, 643-674, 2006.

Diansky, N. A. and Volodin, E. M.: Simulation of present-day climate with a coupled Atmosphere-ocean general circulation model, Izv. Atmos. Ocean. Phys. (Engl. Transl.), 38, 732-747, 2002

Gleick, P. H.: Regional hydrologic consequences of increases in atmospheric carbon dioxide and other trace gases, Climatic Change, 10, 10 137-10 161, 1987.

Gordon, C., Cooper, C., Senior, C. A., Banks, H. T., Gregory, J. M., Johns, T. C., Mitchell, J. F. B., and Wood, R. A.: The simulation of SST, sea ice extents and ocean heat transports in a version of the Hadley Centre coupled model without flux adjustments, Clim. Dynam., 16, 147-168, 2000.

Gordon, H. B., Rotstayn, L. D., McGregor, J. L., Dix, M. R., Kowalczyk, E.A., O'Farrell, S. P., Waterman, L. J., Hirst, A. C., Wilson, S. G., Collier, M. A., Watterson, I. G., and Elliott, T. I.: The CSIRO Mk3 Climate System Model, CSIRO Atmospheric Research Technical Paper No. 60, CSIRO. Division of Atmospheric Research, Victoria, Australia, 130 pp., 2002.

Hamlet, A. F. and Lettenmaier, D. P.: Effects of climate change on hydrology and water resources of the Columbia River Basin, J. Amer. W. Resourc. Assn., 35, 1597-1623, 1999.

Hundley Jr., N.: Water in the West, University of California Press, Berkeley, CA, 1975.

Intergovernmental Panel on Climate Change (IPCC): Climate Change 2001: The Scientific Bias, edited by: Houghton, J. T. and Ding, Y., Cambridge, Cambridge UP, 2001.

Intergovernmental Panel on Climate Change (IPCC): Special report on emission scenarios, Cambridge University Press, New York, 2000 .

Intergovernmental Panel on Climate Change (IPCC): Climate change 2007: Impacts, adaptation, and vulnerability: Working Group II contribution to the Intergovernmental Panel on Climate Change Fourth Assessment Report, Summary for Policymakers, IPCC Secretariat, Geneva, 22 p., 2007.

IPSL: The new IPSL climate system model: IPSL-CM4', Institut Pierre Simon Laplace des Sciences de l'Environnement Global, Paris, France, 73 pp., 2005.
Jungclaus, J. H., Botzet, M., Haak, H., Keenlyside, N., Luo, J.J., Latif, M., Marotzke, J., Mikolajewicz, U., and Roeckner, E.: Ocean circulation and tropical variability in the AOGCM ECHAM5/MPI-OM, J. Climate 19, 3952-3972, 2006.

K-1 model developers: K-1 coupled model (MIROC) description, K-1 technical report, 1, edited by: Hasumi, H. and Emori, S., Center for Climate System Research, University of Tokyo, 34 pp., 2004.

Lettenmaier, D. P., Brettman, K. L., Vail, L. W., Yabusaki, S. B., and Scott, M. J.: Sensitivity of Pacific Northwest water resources to global warming" Northwest Environ. J., 8, 265-283, 1992.

Liang, X., Lettenmaier, D. P., Wood, E. F., and Burges, S. J.: A simple hydrologically based model of land surface water and energy fluxes for general circulation models, J. Geophys. Res., 99(D7), 14 415-14 428, 1994.

Loaiciga, H. A., Valdes, J. B., Vogel, R., Garvey, J., and Schwarz, H.: Global warming and the hydrologic cycle, J. Hydrol., 174, 83-127, 1996.

Maurer, E. P., Lettenmaier, D. P., and Roads, J. O.: Water balance of the Mississippi River Basin from a macroscale hydrology model and NCEP/NCAR reanalysis, EOS, Transactions of the American Geophysical Union, 80(46), F409-410, 1999.

Maurer, E. P., Wood, A. W., Adam, J. C., Lettenmaier, D. P., and Nijssen, B.: A long-term hydrologically-based data set of land surface fluxes and states for the conterminous United States, J. Climate, 15, 3237-3251, 2002.

Maurer, E. P.: Uncertainty in hydrologic impacts of climate change in the Sierra Nevada, California under two emissions scenarios, Climatic Change, 82, 309-325, 2007.

McCabe, G. J. and Wolock, D. M.: General circulation model simulations of future snowpack in the western United States, J. Amer. Water. Resourc. Assn., 35, 1473-1484, 1999.

McCabe, G. J. and Hay, L. E.: Hydrological effects of hypothetical climate change in the East River Basin, Colorado, USA, Hydrol. Sci., 40, 303-317, 1995.

Milly, P. C. D., Dunne, K. A., and Vecchia, A. V.: Global patterns of trends in streamflow and water availability in a changing climate, Nature, 438, 347-350, 2005

Nash, L. L. and Gleick, P.: The sensitivity of streamflow in the Colorado basin to climatic changes, J. Hydrol., 125, 221-241, 1991.

Nash, L. L. and Gleick, P.: The Colorado River Basin and climate change: The sensitivity of streamflow and water supply to variations in temperature and precipitation, EPA, Policy, Planning and Evaluation, EPA 230-R-93-009, December 1993.

Nijssen, B., Lettenmaier, D. P., Liang, X., Wetzel, S. W., and Wood, E. F.: Streamflow simulation for continental-scale river basins, Water Resour. Res., 33, 711-724, 1997.

Russell, G. L., Miller, J. R., and Rind, D.: A coupled atmosphereocean model for transient climate change studies, Atmos. Ocean, 33, 683-730, 1995

Russell, G. L., Miller, J. R., Rind, D., Ruedy, R. A., Schmidt, G. A., and Sheth, S.: Comparison of model and observed regional temperature changes during the past 40 years, J. Geophys. Res., 105, 14 891-14 898, 2000.

Salas-Mélia, D., Chauvin, F., Déqué, M., Douville, H., Gueremy, J. F., Marquet, P., Planton, S., Royer J. F., and Tyteca, S.: Description and validation of the CNRM-CM3 global coupled model, CNRM working note 103, available at: http://www.cnrm.meteo. fr/scenario2004/paper_cm3.pdf, 2005. 
Schuster, R. J.: Colorado River System: System overview, U.S. Bureau of Reclamation, Denver, Colo, 1987.

Seager, R., Ting, M., Held, I., Kushnir, Y., Lu, J., Vecchi, G., Huang, H.-P., Harnik, N., Leetmaa, A., Lau, N.-C., Li, C., Velez, J., and Naik, N.: Model projections of an imminent transition to a more arid climate in southwestern North America, Science Express, 316, 1181-1184, doi:10.1126/science.1139601, 2007.

Snover, A. K., Hamlet, A. F., and Lettenmaier, D. P.: Climate change scenarios for water planning studies, B. Am. Meteorol. Soc., 84, 1513-1518, 2003.

U.S. Department of Interior (USDOI), Bureau of Reclamation: Colorado River Simulation System: System Overview. USDOI Publication, 1985.

U.S. Department of Interior (USDOI), Bureau of Reclamation: Colorado River Interim Surplus Criteria; Final Environmental Impact Statement, Volume 1. USDOI Publication, 2000.

Washington, W. M., Weatherly, J. W., Meehl, G. A., Semtner, A. J., Bettge, T. W., Craig, A. P., Strand, W. G., Arblaster, J., Wayland, V. B., James, R., and Zhang, Y.: Parallel climate model (PCM) control and transient simulations, Clim. Dynam., 16, 755-774,
2000.

Wilby, R. L, Hay, L. E., and Leavesley, G. H.: A comparison of downscaled and raw GCM output: implications for climate change scenarios in the San Juan River basin, Colorado, J. Hydrol., 225, 67-91, 1999.

Wolock, D. M. and McCabe, G. J.: Estimates of runoff using waterbalance and atmospheric General Circulation Models, J. Am. Water Resour. As., 35, 1341-1350, 1999.

Wood, A. W., Leung, L. R., Sridhar, V., and Lettenmaier, D. P.: Hydrologic implications of dynamical and statistical approaches to downscaling climate model outputs, Climatic Change, 62, 189216, 2004.

Woodhouse, C. A., Gray, S. T., and Meko, D. M.: Updated streamflow reconstructions for the Upper Colorado River Basin, Water Resour. Res., 42, W05415, doi:10.1029/2005WR004455, 2006.

Yukimoto, S., Noda, A., Kitoh A., Sugi, M., Kitamura, Y., Hosaka, M., Shibata, K., Maeda, S., and Uchiyama, T.: The New Meteorological Research Institute Coupled GCM (MRI-CGCM2), Model climate and variability, Pap. Meteorol. Geophys., 51, 47$88,2001$. 